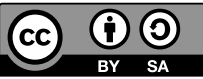

DOI: https://doi.org/10.4312/keria.22.2.85-117

Matej Hriberšek

\title{
Dominik Penn, Lexicographer at the Intersection of Slovenian and Greek
}

\section{ABOUT VID (DOMINIK) PENN}

Dominik or Vid Pen $(n)^{1}$ is one of those Slovenian lexicographers whose work has remained relatively poorly noticed and quite forgotten in the history of Slovenian literature and Slovenian lexicography as well as in the history of classical philology, since he was not a writer who would decisively mark the history of Slovenian or Greek linguistics. He did, indeed, devote more than three decades of his life to the preparation of a dictionary which has never been published but remained in manuscript; due to certain peculiarities, the dictionary and its writer remained anonymous and poorly known or completely unknown to most people. Only scant notes are found about them which are scattered across the scientific and expert bodies of literature, and only one article (Stabej 1975) that somewhat more precisely sketches Dominik Penn's lexicographical and grammatical work. Nevertheless, he was a fascinating and slightly unusual lexicographer of the Slovenian language who included Greek in his work in a very unusual way.

Dominik Penn was born as Vid Penn on 5 May 1785, in the village of Sveti Vid near the town of Ptuj in Slovenian Styria, to father Franc and mother Marija; his Godparents were Mihael and Marjeta Kacijan. ${ }^{2}$ No information or records can be found about his youth. He probably went to primary school in his home town; in 1802, he enrolled in the gymnasium in Maribor, which he attended for six years, between 1802 and 1808. This was relatively late, since he was eighteen years old at the time, i.e. the age at which students usually completed gymnasium. At the time, the closest university

1 In the sources and documents his surname is mostly written with double $n(n n)$, which he used himself also.

2 ŠAM, RMK (Parish register and obituary) Sv. Vid pri Ptuju 1756-1787, p. 325. 
centre for students originating from Styria was the Karl-Franzens-Universität in Graz, Austria, where Vid Penn went in 1808 for a two-year course of studies in philosophy, which was a direct preparation for studying at the university. After these two years of studying philosophy, he enrolled to study theology at the university in Graz; at the end of the 18th century, this was also the only option if one wanted to study theology since that was a period when it was not possible to study it in Ljubljana: Four-year theological studies at the faculty, which had the right to award academic titles, started in Ljubljana in 1811, in the period of the Illyrian Provinces, when the authority over this territory was French. During his school years, he was influenced by a few patriotic individuals who knew how to appeal to the patriotic note in young people and encourage them to be active in the fields of literature, science, and culture. On 13 May 1810, students of Slovenian nationality and young Slovenian intellectuals in Graz, among whom was most probably also Vid Penn (even though this has not been documented), joined in the so-called Slovensko društvo (Societas Slovenica), which was headed by the Slovenian teacher and intellectual Janez Nepomuk Primic; the primary mission of the society was to preserve the Slovenian language, its research, and to collect the Slovenian linguistic material. ${ }^{3}$ During his study of theology, Vid Penn decided that he would not work as a regular diocesan priest but entered the order of Friars Minor and chose his monastic name Dominik. He completed the study of theology in 1814; on 21 September of the same year he was ordained. As a priest he functioned only locally, on the narrow area of his home town and its surroundings in parishes run by Friars Minor: first, he was a chaplain in the parish of Sveta Trojica (The Holly Trinity, now Podlehnik) in Haloze until 1829, which was under the care of friars from the Minorite monastery; during this time, he was in close contact with his friend from his student years, Anton Krempl (1790-1844). ${ }^{4}$ In 1829, he took over his home parish of Sveti Vid (Saint Vitus) near Ptuj, which he ran until 1844; that year, he returned to Ptuj, where he became the monastery vicar and one of the members of the definitory of the Minorite province. He worked here until 14 April 1855, when his heart gave out and he was buried on 16 April in the cemetery near the church of St. Ožbalt in Ptuj. ${ }^{5}$

3 See Šumrada (2002), Slodnjak (2013), Kidrič (1934 a-b), Kidrič (1929: 381-383, 430-440, 483-546, 573-589), Legiša (1959: 36-38), von Wurzbach (1872: 309-310), Prunč (1983: 281).

4 See Glazer (2013-a), Raič (1869), Medved (1895), Macun (1883: 8o-83), Glaser (1896: 183-184).

5 See Ilešič (1905: 6, 7, 10), Kidrič (1930: 80, 92, 229, 273), Kidrič (2013-c), Stabej (1975: 42). 


\section{PREVIOUS DISCUSSIONS}

Not counting the sporadic mentions of the dictionary and Penn himself, the dictionary did not receive detailed study until the second half of the 20th century. It is interesting that later literary historians practically never mention him; and it is truly surprising that he is not mentioned even by Ivan Macun in his work Književna zgodovina Slovenskega Štajerja (Literary History of Slovenian Styria), the review of literary creativity in Styria. ${ }^{6}$ The only exception is France Kidrič, who first mentioned him in 1929 in his Zgodovina slovenskega slovstva (History of Slovene Literature), where he primarily stresses the role of Penn as a revivalist in Styria and his participation in the circle of Slovenian students and intellectuals in the time when he studied theology in Graz. ${ }^{7}$ A year later (1930), he presented D. Penn and his references in the sources of his work about Dobrovský and his age, and he also wrote a short presentation of Penn's life and work for the Slovenski biografski leksikon (Slovenian Biographical Lexicon). ${ }^{8}$ The most in-depth discussion about Penn's dictionary, which has remained unnoticed until now, was published by Jože Stabej in the magazine Slavistična revija quarterly (Stabej 1975). In the last twenty years, the dictionary has been dealt with by Marko Jesenšek. ${ }^{9}$

\section{THE DISCOVERY OF THE DICTIONARY}

At the time when dictionary material was being collected and his dictionary made, Penn's lexicographical work was entirely unknown; it was familiar only to rare individuals who, like Penn, collected Slovenian vocabulary units. Indirectly, Penn's work was connected to the creation of the Slovenian-German dictionary, which Fran Miklošič started writing in 1849 (Ilešič 1905: 88). In collecting linguistic material, Miklošič was aided by some of the Slovenian students in Vienna, including Ivan Ertl (Ilešič 1905: 87-88, Kotnik 1919). He invited everyone who would be prepared to either collect the material or hand over previously prepared collections of words to join him; he also addressed his acquaintances to help him collect the dictionary material. In a letter of January 1850 (precise date unknown), he wrote to Jožef Muršec: ${ }^{10}$

6 Cf. Šlebinger (2013).

7 See Kidrič (1929: 458, 494, 496, 575).

8 See Kidrič (1930: 80, 92, 229, 273), Kidrič (2013-c).

9 See Jesenšek (1999-b: 369-370), Jesenšek (2015: 351-352).

10 About Muršec see Ditmajer (2019: 6-22), Vrbanov (1898), Macun (1883: 123-125), Legiša (1959: $157,165)$. 
Dragi prijatelj! ...

Ja sem sklenil izdati slovensko-nemški rečnik: kar sem skoz dolge leta nabral, zdaj s pomočjo svojih dobrih prijateljev v Beču dopolnjavam. Ali če učeni ljudje v slovenskih deželah meni ne pomorejo, delo ne bo moglo doseči tiste popolnosti, ktero toliko želim. Zato Vas lepo in lepo prosim, naj se Vam rači meni poslati če kako zbirko slovenskih besed pripravljeno imate: Ertel, kteri mi je od velike pomoči v mojem delu, mi je rekel, da tako zbirko imate. Ja sem dobil dve zbirki: Kopitarjevo, Rudeševo in celo kratko Ravnikarjevo. Poznate li Vi koga, ki bi tako zbirko imel, ali ki bi mogel in htel meni pomagati? Jaz rad platim, če kdo kaj za me včini. Morebiti bi v semenišču se kdo najšel ...

Dear friend! ...

I've decided to publish a Slovenian-German dictionary: what I have gathered over many years, I'm now supplementing with the help of my good friends in Vienna. But if learned people in Slovenian lands don't help me, the work won't be able to achieve the perfection I'm striving for. Therefore, I kindly ask you to be willing to send me a collection of Slovenian words, if you have one prepared: Ertl, who is of great help to my work, told me you might have such a collection. I have received two collections: one from Kopitar and one from Rudeš, and even a short one from Ravnikar. Do you know of anyone else who might have such a collection or who could and would want to help me? I gladly pay if someone does something for me. Maybe someone could be found at the seminary... (Ilešič 1905-a: 88, 1905-b: 158)

Fran Miklošič solicited assistance from a wide circle of Slovenian intellectuals who would collect for him primarily less known Slovenian words against payment; they sought help from the wider public, since the project was obviously seriously thought through. The only thing missing was people who would help collect the material, since Miklošič himself could not devote his time to this task due to his obligations in Vienna. On 23 July 1851, an unsigned author published Miklošič's invitation in Novice ${ }^{11}$ and presented a few individuals who were collecting linguistic material around the Slovenian national territory. At the same time, the author encouraged everyone who would be willing to embark on this task to join in. This article mentions Penn for the first time:

Gosp. dr. Miklošič misli tudi nabirek g. Penna, minorita v Ptujem, (kteri se neki že 30 lét $\mathrm{z}$ nabiranjem slovenskih beséd peča), kakor tudi mnogoletni gosp. Cafov nabirek kupiti, ako ju bo volja prodati.

11 The author was presumably Matej Cigale. See Breznik (1938: 155). 
Dr. Miklošič intends to buy the collection of Mr. Penn, a Friar Minor from Ptuj (who has been dealing with the collection of Slovenian words for some 30 years now), as well as the collection of Mr. Caf, if they are willing to sell them.

("Dopisi," Novice kmetijskih, rokodelnih in narodskih rečí 9, 30 (1851) [sreda, 23. maliga serpana (srednoletna)]: 151)

However, Miklošič never published the intended dictionary, but did help with its creation in Ljubljana. Maks Pleteršnik, who as the editor oversaw the publication of the Slovensko-nemški slovar, explicitly wrote in the introduction to the dictionary in 1893: "Professor Dr F. Miklošič also gave his SlovenianGerman dictionary (a manuscript in four volumes, containing 287 sheets) for the board to use." Yet, Pleteršnik does not mention Penn and his dictionary among the sources from which the composers of the dictionary drew the Slovenian words; obviously, his dictionary had been forgotten by then or they simply did not know of the lexical material (see Pleteršnik [1893] 1894-1895: iii).

What happened with the dictionary after Penn's death was clearly unknown; in periodical Slovenski glasnik for 1858, a writer (probably the editorin-chief Anton Janežič) wrote that he had received a letter from one of his friends in Styria, in which this friend familiarises him with Penn's dictionary:

Iz prijateljskega dopisa iz Štajerskega tole: Pravil mi je pred nedavnim nek rodoljub o slovenskem slovarju v rokopisu, ki ga je spisal po šestnajstletnem trudu P. Dominik v Ptujem 1. 1845. Obsegal je po pisateljevih besedah 20-30 tisuč besed, in samo za dele v očesu je imel blizo 20 izrazov. Govorilo se je, da misli g. pisatelj svoje spise na Dunaj poslati - pa kdo ve, kje so sedaj? Škoda velika za lepo nabero, če se je zgubila.

From a friend's letter from Styria: I was told recently by a patriot about a Slovenian dictionary in manuscript that was compiled after the sixteen-year labours of F. Dominik in Ptuj in 1845. According to the author, it was compiled of 20-30 thousand words, and for parts of the eye alone he had nearly 20 expressions. It was said that the writer intended to send his documents to Vienna-does anyone know where are they now? It would be such a great shame if such a big collection were to be lost. (Janežič 1858: 172)

It is clear from the letter that neither Janežič nor his friend knew that the dictionary had been bought by Fran Miklošič, who had been interested in the purchase even before then. One question remains open: was the mediator between Penn and Miklošič the famous Slovenian linguist and collector of linguistic material Oroslav Caf? ${ }^{13}$ Caf's biographer Božidar Raič mentions that

12 See Breznik (2013), Pirjevec (1924), Pleteršnik ([1893] 1894-1895).

13 See Raič (1878), Kolarič (2013-a), Toš (2014), Šrimpf (1972). 
in 1856 Miklošič came to visit Caf and suggested that they publish a dictionary he was preparing together, but Caf turned down the invitation to collaborate (Raič 1878: 82). Was it Oroslav Caf who gave Fran Miklošič Penn's dictionary? The preserved sources do not confirm such a conclusion; in any case, Caf was in possession of Penn's manuscript, yet it is unknown whether that was while Penn was still alive or after his death. First, this is indicated by an almost unnoticeable notice on page 86 of the German-Slovenian dictionary at the

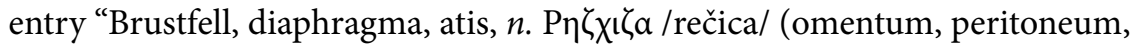
diaphragm)", where Caf added the Slovenian meaning 'rečica' and signed his name (Image 1).

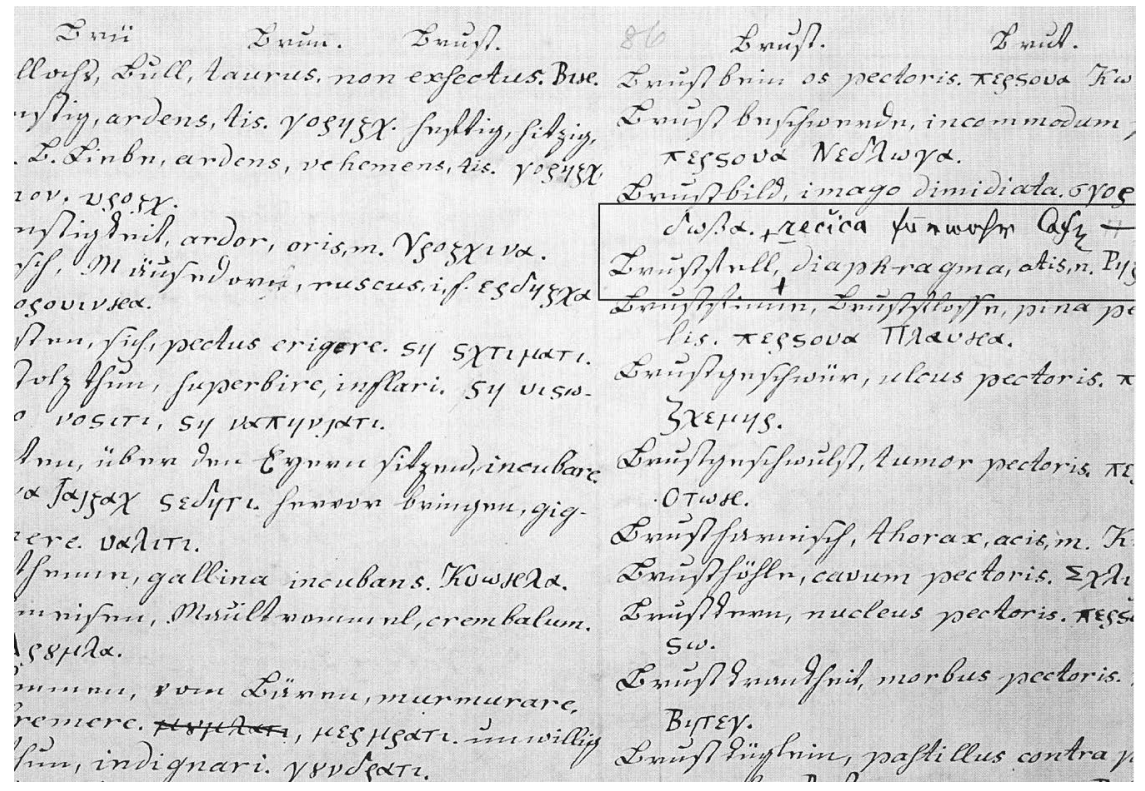

Image 1: Oroslav Caf's addition in Penn's dictionary, p. 86; source: NUK, Ms.

The second confirmation is found in Caf's letter to Božidar Raič, in which he was asking him about the word "skabica" that he found in Penn's material (Raič 1878: 86). It is certain that the dictionary found its way to Miklošič, who later sent it to Slovenian lexicographer Matej Cigale, ${ }^{14}$ who explicitly wrote this in his introductory review of the history of Slovenian lexicography two years later (1860), when he published his Deutsch-slovenisches Wörterbuch (Nemško-slovenski slovar, German-Slovenian Dictionary), the printing of which was sponsored by the Ljubljana bishop Anton Alojz Wolf. This is where we find more concrete information about Penn's dictionary for the first time:

14 See Atelšek (2013), Kolarič (2013), Kacin (2013). 
Von Herrn Professor Dr. Fr. Miklošič erhielt ich ein deutsch-lateinisch-windisches Wörterbuch des verstorbenen Pettauer Minoriten Penn (vollendet 1854), in welchem das Slovenische ungeschickt genug mit griechischem Alphabet geschrieben ist, das aber insoferne eine Beachtung verdient, als es aus einer lexikographisch noch wenig durchsuchten Gegend stammt.

I've received a German-Latin-Slovenian dictionary by the late Friar Minor Penn from Ptuj (finished in 1854) from professor Dr Fran Miklošič, in which Slovenian is quite awkwardly written in the Greek alphabet, but which is all the more worth noticing because it originates from a lexicographically poorly researched area.

(Cigale 1860, 1: vii)

What happened to the dictionary after Cigale got it from Miklošič is not known; it is last mentioned by Oroslav Caf in 1871. Caf publicly asked Slovenian intellectuals who was it that had offered him for transcription the manuscript by the Maribor Capuchin Friar Bernard or Ivan Anton Apostel a while back (1760); ${ }^{15}$ in his inquiry, he also awoke the memory of Penn: "Our Maribor has even two lexicographers: a friar Bernard and priest Narat ... as Ptuj has its own: Pen and Kupan" (Caf 1871: 1). The material of Penn's dictionary (similar to Miklošičss before him) was used by Caf in the preparation of his own dictionary material which was the base of Pleteršnik's dictionary (Jesenšek 1999-b: 370). After that, Penn and his dictionary sank into oblivion; it is not known what happened to the manuscript, but the dictionary was apparently left to be kept by Slovenska matica (possibly from Fran Ilešič), which later handed it over to the National and University Library (there are no precise data), where it is kept in the Manuscript Collection. ${ }^{16}$

\section{THE PREFACE AND THE FIRST PART OF THE DICTIONARY}

Penn's dictionary was being composed in the period between 1824 and 1845, and then he continued to supplement it until 1854. A clean copy of the dictionary was supposedly made sometime between 1846 and 1854 (Stabej 1975: 55). The dictionary's manuscript encompasses a total of 590 pages in the size 47 x $22 \mathrm{~cm}$ and is subdivided into three parts: The first, most extensive part,

15 UKM, Ms 195 (F 83), Dictionarium Germanico Slavonicum, Vocabula tam Antiqua, quam Nova, usu recepta, juxta Etymon purioris Slavonismi Authorum, Methodice demonstrans ... Authore $P(a t) r e$ Bernardo Marburgensi, Capucino. [Maribor] 176o. See Ilešič (1939), Vidmar (2013), Kidrič (2013-a), Stabej (1972), Jesenšek (1999: 360-361), Legiša (1959: 304-305), Kidrič (1929: 149, $151,201,204,256,258,717)$.

16 NUK, Ms 1313, Deutsch-lateinisch-und windisches, dann windisch-deutschesWörterbuch Am Ende mit einem deutschen, lateinischen, windischen Alfabeticum, wie auch mit einer windischer Sprachlehre herausgegeben. 
which has 471 pages, is the German-Latin-Slovenian dictionary comprising (approximately) 57,000 Slovenian words (Stabej 1975: 47); the author gave it a lengthy title:

Deutsch-lateinisch-windisches, dann windisch-deutsches Wörter-Buch zum allgemeinen / Gebrauche, besonders für die Geschäfts-Männer sowohl im weltlichen als geistlichen Stande in / den slovenischen Ländern, mit allen Bedeutungen einzelner Wörter und Redensarten. Am Ende / mit einem deutschen, lateinischen und windischen Alfabeticum, wie auch mit einer windischen / Sprachlehre, herausgegeben. / Deutsch-lateinisch-windisches Wörterbuch erster Theil Im Jahre 1854.

German-Latin-Slovenian, then Slovenian-German dictionary for general / use, especially for businessmen both of secular and clerical status in / Slovenian lands, with all meanings of individual words and phrases. / In the end with the German, Latin, and Slovenian alphabet, published along with / the Slovenian grammar. / German-Latin-Slovenian dictionary, the first part in 1854.

It is not known where Penn's stimuluses came from for the collection of lexicographic material; supposedly, friends he knew from the Societas Sloveni$c a$ while he was studying theology in Graz encouraged him to do this work when he was starting his career as a chaplain in Ptuj, therefore around 1820. The indirect cause for the work and its background can be discerned from the foreword written to the first part of his dictionary (Image 2). The main points from the introduction are:

- that a comprehensive German-Slovenian and Slovenian-German dictionary has never been created;

- that such a dictionary is essential for businessmen (he emphasised this twice; he probably has merchants in mind);

- that in many parts of the Slovenian territory, German and barbaric expressions have sneaked into the Slovenian language (this idea is repeated twice in the introduction);

- that the Slovenian language has got corrupted because true Slovenian words are being forgotten;

- that the dictionary offers authentic Slovenian words collected by the author from people who still speak the "uncorrupted" language;

- that the base for the dictionary is Schönberger's German-Latin dictionary;

- that he has sought authentic expressions for all words and phrases, lands and towns in Europe, tree species, bushes, vines, herbs, livestock, birds, insects, fish, body parts, tools, etc.;

- that numerous words included in the dictionary will be criticised;

- that the vocabulary of his dictionary is authentically Slovenian. 


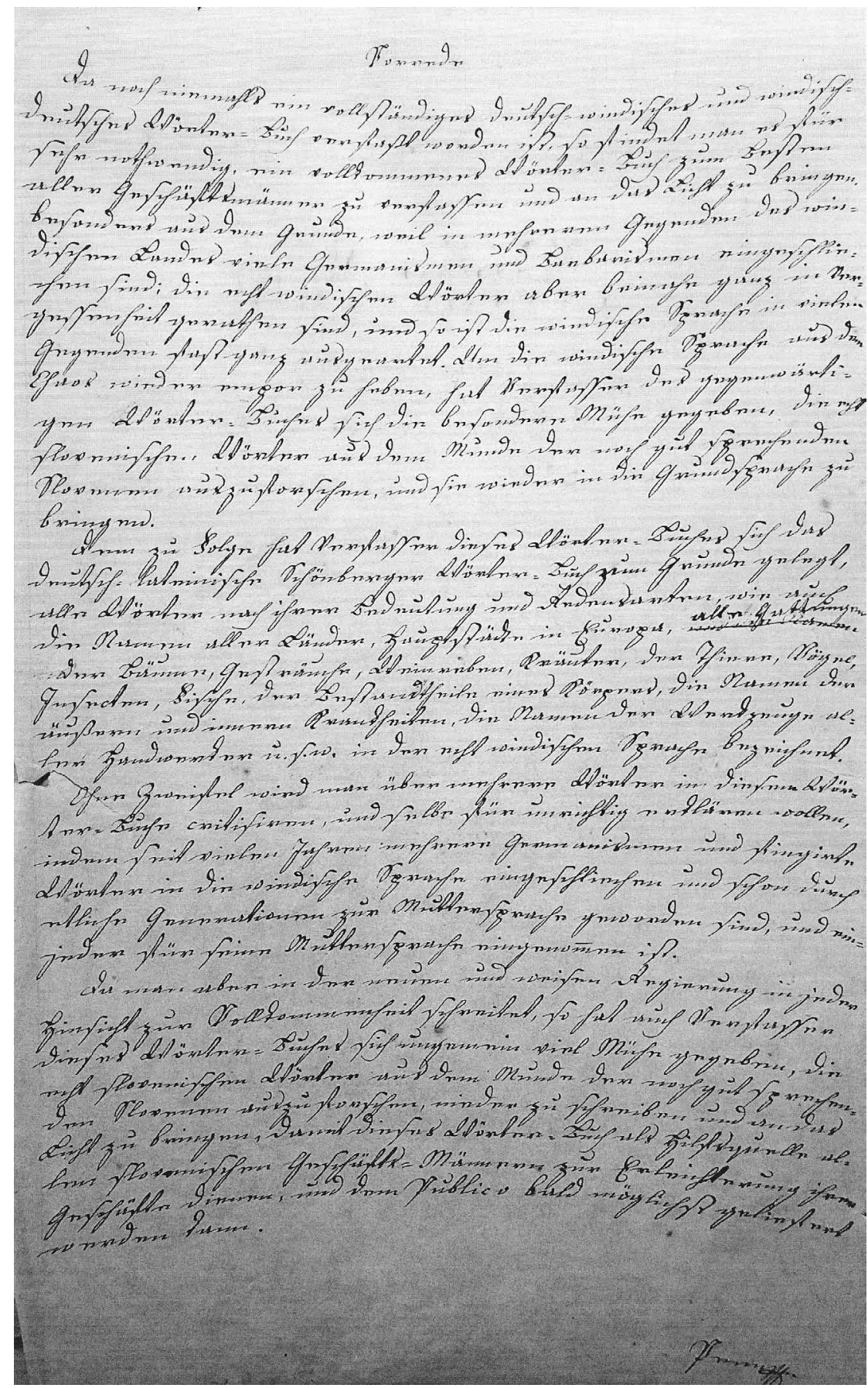

Image 2: Dominik Penn, Deutsch-lateinisch-windisches ... Wörter-Buch (1854), foreword (Vorrede); source: NUK, Ms. 
The introduction is unusual especially due to Penn's statement that there has never been a German-Slovenian and a Slovenian-German dictionary written. This was not true since he could use in his work at least five contemporary dictionaries: the third edition of Megiser's Dictionarium quatuor linguarum, published in 1744 in Klagenfurt on the Jesuits' initiative, ${ }^{17}$ Pohlin's Tu malu besedishe treh jesikov (1781) ${ }^{18}$ and Glossarium slavicum (1792), Gutsman's Deutsch-windisches Wörterbuch (1789), ${ }^{19}$ Jarnik's Versuch eines Etymologikons der slowenischen Mundart in Inner-Österreich (1832), and Murko’s Şlovénskonémshki in némshko-şlovénski rózhni besédnik (1832-1833); ${ }^{20}$ his sources could also have included both dictionaries by Anton Janežič: Popólni ročni slovár slovenskega in nemškega jezika (1850) and Vollständiges Taschen-Wörterbuch der slovenischen und deutschen Sprache (1851) (Murko 1832-1833). These dictionaries must have been known and used by Penn; why he decided to conceal this fact is not known. Next in the introduction, he speaks about German words, barbaric expressions and corrupted words, which had sneaked into the Slovenian language and corrupted it. It is difficult to decide exactly which expressions he had in mind, since he himself included in his dictionary a plethora of German words, which had indeed been established in both the Slovenian literary language and in its dialectal variants; he originated from an environment in which the language was distinctly dialectally marked (Image 3). A few examples:

- Slo. cagati-Ger. zagen (Eng. to hesitate, to linger);

- Slo. erb-Ger. der Erbe (Eng. heir);

- Slo. jamrati-Ger. jammern (Eng. to groan, to moan);

- Slo. gvišno-Ger. gewiss (Eng. certainly, sure);

- Slo. knof-Ger. der Knopf (Eng. button);

- Slo. nucati-Ger. nutzen, nützen (Eng. to use, to be useful);

- Slo. štala-Ger. Stall (Eng. stable, stall), etc.

17 Megiser, Dictionarium quatuor linguarum; see Hriberšek (2008), Logar (2013), Legiša (1959: 251-252), Kidrič (1929: 47, [51], 53, [57, 73], 78, [78], 83, [84, 89], 90, 109, [110], 113, [121, 123, 124], $125,127,[127], 128,129,130,131,[134,135], 136,142,237,238,251,389,405,422,491,717)$.

20 See Macun (1883: 109-112), Pajek (1880), Glazer (2013), Jesenšek (1999-a), Hartman (1998). 


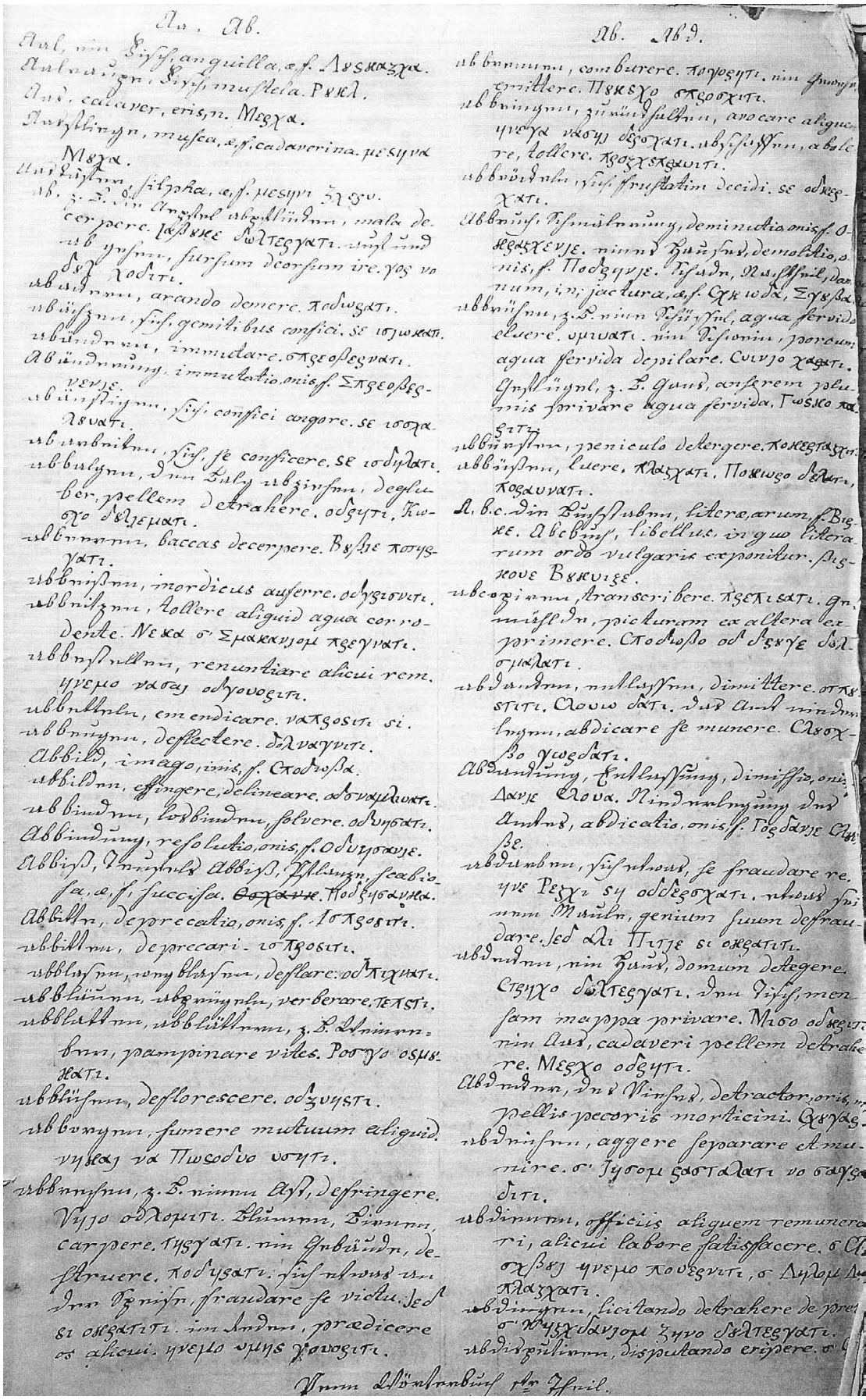

Image 3: Example from Penn's Deutsch-lateinisch-windisches ... Wörter-Buch (1854), p. 1; source: NUK, Ms. 
All of the above and many other expressions are classified by contemporary Slovenian lexicography as non-literary, colloquial, or folk expressions. Again, it is not known whether the preface to the dictionary is Penn's own work; it is quite possible that he recapped it from some other dictionary or manuscript and did not mention it.

Penn chose the work of an Austrian school teacher and scholar Andreas Corsinus (Franz Xaver) Schönberger (1754-1820), ${ }^{21}$ deserving for the advancement of the classical educational system and a very prolific expert writer, for the basis of his dictionary. His greatest achievement was the transformation of Scheller-Lünemann's Latin-German and German-Latin dictionary, which was published in Vienna in 1818-1820 in three volumes (Scheller, Lünemann, and Schönberger 1818-1820), with which he wanted to provide an appropriate dictionary for high schools and universities in Austria, and also for general business use, since Schönberger mentions in his introduction that the dictionary could also be of use to businessmen; this additionally proves that Penn indeed leaned on his work since he uses the same formulation in the introduction of his own dictionary. Schönberger's dictionary was thus the framework for the collection of Slovenian words.

Entries in the German-Latin-Slovenian part of the dictionary are listed in alphabetical order of the German alphabet. The German entry is always written first, then Latin, and Slovenian at the end; often, word phrases are presented alongside entries. The first part includes entries from "Aal, ein Fisch,

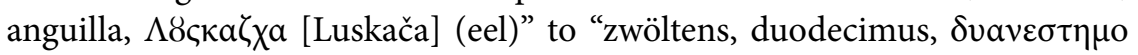
[dvanestemo] (twelfth)".

\section{5. "GRŠČICA"}

Dominik Penn was quite an eccentric among Slovenian lexicographers due to his manner of recording dictionary material. Specifically, he wrote in uniform, well readable writing which is the same throughout the manuscript. He wrote German words in small letters Gothic script; there are no peculiarities in recording. He wrote Latin words in Latin script, for which it is characteristic - as is also stated by Stabej $(1975,47)$ - that the letter $q$ is always written as $g$, although a small difference can frequently be noticed between $g$ and $q$, for example: Aequator 'equator'-circulus aequinoctialis, Adler 'eagle'-aguila, alltäglich 'quotidian'-guotidianus, nicht einmal 'not even'-nec ... guidem, aliguid $=$ aliquid, acguirere $=$ acquirere, etc. That which connects Dominik Penn's dictionary to Greek is the way he wrote Slovenian words. For that, Penn introduced writing in the Greek alphabet, which earned this writing the name

21 See von Wurzbach (1876), Harrauer-Reitterer (1995). 
"grščica”. And this is where the peculiarity of Penn's dictionary lies, which made him the biggest character among Slovenian lexicographers.

Why use Greek letters to write down Slovenian words? The period in which Dominik Penn's dictionary was created coincided with a special phenomenon in the history of Slovenian linguistics called the "Slovenian alphabetic war" or "črkarska pravda". It had to do with the polemic that arose among Slovenian linguists as to which script should replace the Bohorič alphabet ("bohoričica") used until then, for which the rules were set by Adam Bohorič ${ }^{22}$ the Slovenian Protestant writer and author of the first Slovenian grammar written in Latin Arcticae horulae succissivae (Slo. Zimske urice proste, Eng. Free Winter Hours), which was published in 1584 in Wittenberg. Hence, in the time of Dominik Penn, the Bohorič script had been used for 250 years and in the first third of the 19th century tendencies appeared for the introduction of a new script. Two new alphabets appeared as the competition to the Bohorič alphabet which were suggested by two Slovenian linguists:

- "dajnčica", the Dajnko alphabet, which was proposed in 1824 by the linguist and religious writer Peter Dajnko (1787-1873) in his work Lehrbuch der windischen Sprache (The Textbook of Slovenian Language), ${ }^{23}$ and

- "metelčica", the Metelko alphabet, which was proposed in 1825 as a substitution for the Bohorič alphabet by the Slovenian linguist, writer, and translator Franc Serafin Metelko (1789-1860) in his work Lehrgebaude der slowenischen Sprache in Königreiche Illyrien und in den benachbarten Provinzen (Textbook of the Slovenian Language of Kingdom of Illyria and Neighbouring Provinces) and which enjoyed the support of the renowned Slavicist Jernej Kopitar (1780-1844). ${ }^{24}$

Each of these alphabets brought something new to the writing of the Slovenian language, yet neither of them asserted itself, primarily due to Slovenian intellectuals of a younger generation, especially the poet France Prešeren (1800-1840) and linguist, literary historian, and critic Matija Čop (17971835); metelčica was thus prohibited in 1833 and dajnčica six years later, in 1839. The Bohorič alphabet therefore remained in use and was supplanted in the mid-19th century by the new Latin alphabet called "gajica", the (Ljudevit) Gaj alphabet. ${ }^{25}$ Penn decided to take a completely different path; Marko Jesenšek assumes that the decision for "grščica" was his escape route because he did not want to add to the already strained relations between the defenders and opponents of "danjčica" and eastern-Styrian literary language. ${ }^{26}$

\footnotetext{
22 See Ahačič (2013), Ahačič (2007: 69-214).

23 See Kidrič (2013-b), Dajnko (1824), Rajhman (1998), Stabej (2001), Rajh (1998).

24 See Metelko (1825), Kolarič (2013-c), Prijatelj (1935: 84-85, 96, 124-125, 143), Lokar (1957-1958).

25 See Fekonja (1891), Petrè (1939), Lenard (1909), Štrekelj (1922).

26 See Jesenšek (1999-b: 369-370), Orel (2017: 260).
} 
For his "grščica" he even had to design the rules for writing. Therefore, at the end of his dictionary, Penn added a special chapter entitled "Empfehlung der griechischen Buchstaben” (Slo. Priporočilo grških črk, Eng. Recommendation of Greek Letters; see Image 4 and Image 5) in which he presented his writing and the system of recording it in a table, while at the same time, he also substantiated his decision in an additional explanation, the main emphasises of which are:

- once upon a time the Greeks transformed the ancient Slavic letters;

- the merit of the Greeks is that they simplified the letters;

- thus, they invented the short and long $e$, as well as the short and long $o$, in order for the length of the syllable to be pronounced correctly;

- they also accepted the soft and sharp $s$;

- such writing is useful and inevitably necessary for Slovenian, thus he recommends it for more than one reason.

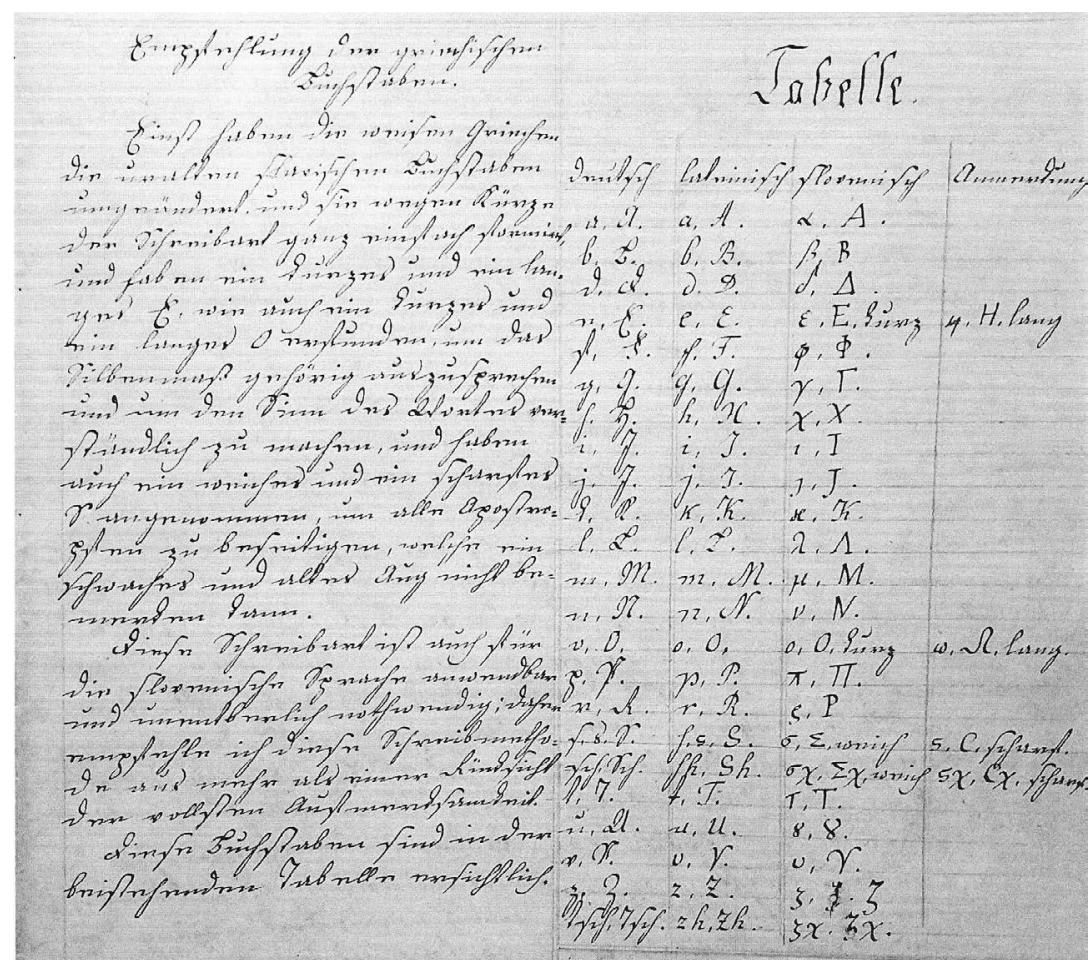

Image 4: Dominik Penn, Windisch-deutsches Wörter-Buch (1854), p. 81, Empfehlung der griechischen Buchstaben - 1; source: NUK, Ms. 


\section{Aflubaticino}

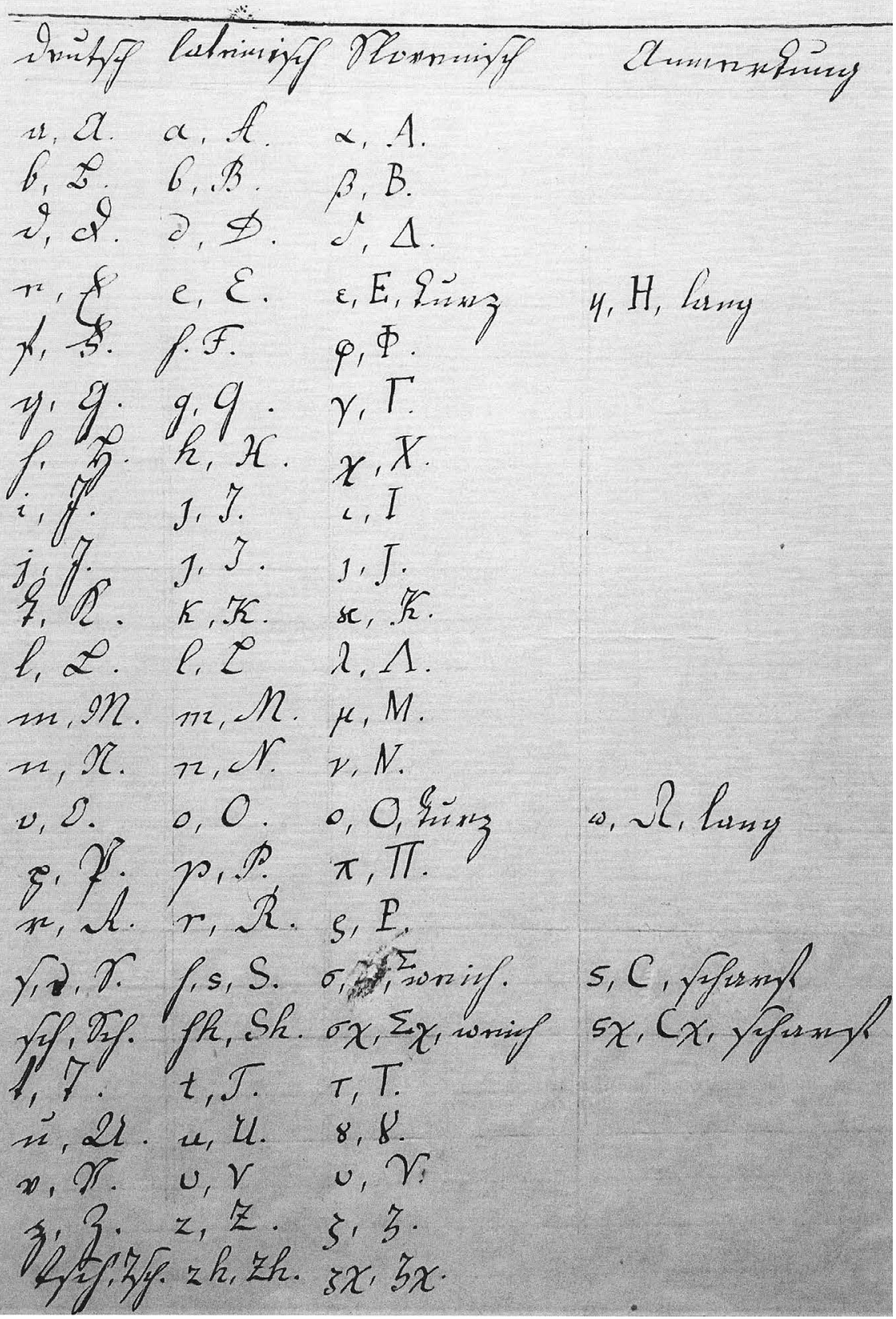

Image 5: Dominik Penn, Windisch-deutsches Wörter-Buch (1854), Alfabeticum; source: NUK, Ms. 
Dominik Penn's explanation actually does not offer any tangible information why he decided to write Slovenian words in the Greek alphabet. However, two things can be discerned from the afore-stated: that he was, in a similar way to numerous other Slavic experts of his time, convinced that the Slavic alphabet (including the Slovenian) was older than the Greek, and that he found the Greek alphabet useful because it differentiates between the long and short $e$ and the long and short $o$ and the soft and sharp $s$.

Table 1: Penn's system of writing Slovenian with Greek letters

\begin{tabular}{|c|c|c|}
\hline German & Latin & Slovenian \\
\hline a, $\mathbf{A}$ & $\mathrm{a}, \mathrm{A}$ & $\alpha, A$ \\
\hline b, B & $\mathrm{b}, \mathrm{B}$ & $\beta, B$ \\
\hline d, D & $\mathrm{d}, \mathrm{D}$ & $\delta, \Delta$ \\
\hline$e, E$ & $e, E$ & $\begin{array}{l}\varepsilon, \mathrm{E} \text { (short) } \\
\eta, \mathrm{H} \text { (long) }\end{array}$ \\
\hline$f, F$ & $\mathrm{f}, \mathrm{F}$ & $\varphi, \Phi$ \\
\hline g, G & $\mathrm{g}, \mathrm{G}$ & $\gamma, \Gamma$ \\
\hline h, H & h, $\mathrm{H}$ & $x, X$ \\
\hline $\mathrm{i}, \mathrm{I}$ & i, I & $\mathrm{l}, \mathrm{I}$ \\
\hline $\mathbf{j}, \mathbf{J}$ & $\mathrm{j}, \mathrm{J}$ & $\mathrm{j}, \mathrm{J}$ \\
\hline $\mathrm{k}, \mathrm{K}$ & $\mathrm{k}, \mathrm{K}$ & $\kappa, \mathrm{K}$ \\
\hline $1, \mathrm{~L}$ & $1, \mathrm{~L}$ & $\lambda, \Lambda$ \\
\hline $\mathbf{m}, \mathbf{M}$ & $\mathrm{m}, \mathrm{M}$ & $\mu, \mathrm{M}$ \\
\hline $\mathrm{n}, \mathrm{N}$ & $\mathrm{n}, \mathrm{N}$ & $v, \mathrm{~N}$ \\
\hline $\mathbf{o}, \mathbf{O}$ & o, $\mathrm{O}$ & $\begin{array}{l}\text { o, } \mathrm{O} \text { (short) } \\
\omega, \Omega \text { (long) }\end{array}$ \\
\hline $\mathrm{p}, \mathbf{P}$ & $\mathrm{p}, \mathrm{P}$ & $\pi, \Pi$ \\
\hline $\mathbf{r}, \mathbf{R}$ & $\mathrm{r}, \mathrm{R}$ & $\rho, P$ \\
\hline$f, s, S$ & $f, s, S$ & $\begin{array}{c}\sigma, \Sigma \text { (sharp) } \\
\varsigma, \mathrm{C} \text { (soft) }\end{array}$ \\
\hline sch, Sch & sh, Sh & $\begin{array}{c}\sigma \chi, \Sigma \chi \text { (sharp) } \\
\varsigma_{\chi}, C_{\chi} \text { (soft) }\end{array}$ \\
\hline$t, T$ & $\mathrm{t}, \mathrm{T}$ & $\tau, \mathrm{T}$ \\
\hline $\mathbf{u}, \mathbf{U}$ & $\mathrm{u}, \mathrm{U}$ & 8,8 \\
\hline $\mathbf{v}, \mathbf{V}$ & $\mathrm{v}, \mathrm{V}$ & $v, \Upsilon$ \\
\hline $\mathrm{z}, \mathrm{Z}$ & $\mathrm{z}, \mathrm{Z}$ & $\zeta, \mathrm{Z}$ \\
\hline tsch, Tsch & $\mathrm{zh}, \mathrm{Zh}$ & $\zeta_{\chi}, Z_{\chi}$ \\
\hline
\end{tabular}


How D. Penn solved problems with the writing and how he adapted the Greek alphabet to write Slovenian words in the so-called grščica:

1. for the short $e$ he used the Greek epsilon $(\varepsilon, \mathrm{E})$ and for the long $e$ the Greek letter eta $(\eta, \mathrm{H})$;

2. for the short $o$ he used the Greek omicron $(\mathrm{o}, \mathrm{O})$ and for the long $e$ the Greek letter omega $(\omega, \Omega)$;

3. the letter $s$ : for the sharp $s$ he uses the normal letter sigma $(\sigma, \Sigma) s$, for the soft $s$ he used the final Greek sigma $(\varsigma, \mathrm{C})$; the capital letter is probably the sigma lunatum, but it could be the Cyrillic $s, C$ (it is not clearly definable from the records);

4. for the letters $z, Z$ he uses the Greek letter sigma $(\sigma, \Sigma)$;

5. sibilants-letters $\check{c}, \check{C}, \check{s}, \check{S}, \check{z}, \check{Z}$ he composed from the Greek letters zeta and $h i\left(\zeta_{\chi}, Z_{\chi}\right)$ and the combination of letters sigma and $h i\left(s \chi, C_{\chi}, \sigma \chi, \varsigma_{\chi}\right.$, $\Sigma \chi)$

6. the letter $j$, $J$, for which there is no sign in the Greek alphabet, was taken from the Latin alphabet;

7. for the letters $u, U$ he did not take the Greek ov, but used the Old Church Slavonic sign $u k(8,8)$, which replaced the digraph ou;

8. for the letters $v, V$ he used the Greek upsilon $(v, \Upsilon)$.

It is also interesting that he wrote nouns with a capital letter (Image 6), even though there was no special reason for it (it is quite possible that in doing so he was influenced by the German language), while verbs, adjectives, and

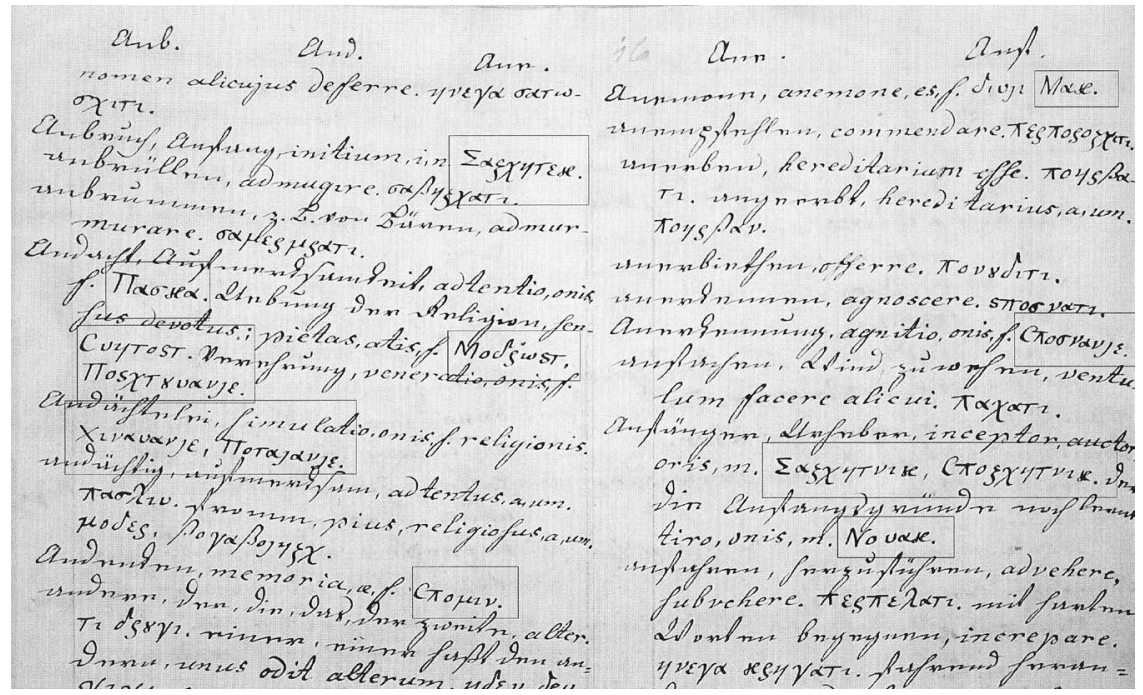

Image 6: Dominik Penn, Deutsch-lateinisch-windisches ... Wörter-Buch (1854), p. 16, examples of capital letters; source: NUK, Ms. 
other word types were not. For nouns, he never recorded the genitive case or their gender, while for verbs, he always wrote only the basic dictionary form, i.e. the infinitive. The German-Slovenian dictionary includes a few examples of nouns in which he used $\Gamma$ instead of the capital letter $\Lambda$; the reason is unknown (it could be a mistake). When writing Slovenian words in the Greek alphabet, he never used diacritic marks and when writing Latin nouns, he frequently added the genitive and gender.

\section{VOCABULARY}

Dominik Penn was well versed in grammatical rules and spelling tendencies of his time, which is clear from the writing of the vocabulary. Slovenian vocabulary (a more detailed analysis of this has not yet been done for Penn's work, only a few more extensive case studies) in his dictionary can be divided into three groups.

The first group includes words which can be designated as literary and their use was set throughout the entire territory populated by Slovenianspeaking people.

The second group is composed of words which are typically dialectal and were taken by Dominik Penn from his native, Eastern-Styrian dialect; he collected many of these on his own, but had some help in the existing printed sources, among which the Slovensko-nemški in nemško-slovenski slovar, which was published in 1833 by the Slovenian grammarian and lexicographer Anton Murko (1809-1871), ${ }^{27}$ stands out the most; since many of these words can be found also in other lexicographers who were Dominik Penn's contemporaries, while Slovenian writers often used them in the writing of their books, newspaper as well as periodical articles, it is impossible to determine which were his direct sources. In general, the words taken from dialectal speech Penn characteristically wrote in dialect. A few examples of such dialectal words: $\kappa \eta \rho \mathrm{[keri]}$ welcher (which); $\vee \eta \kappa \varepsilon \delta \alpha$ [nekeda] dereinst, einstmals, einst, ehemals (once); $\pi \delta \chi$ [p(o)uh] Bilchmaus, Hasselmaus, Rellmaus (dormouse); $\pi \delta 8 \chi$ [p(o)už]

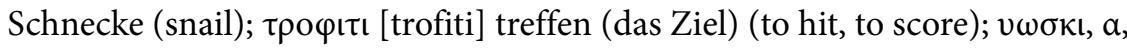
o [voski] schmahl, schmal, eng (narrow, tight); etc.

A completely special chapter of Dominik Penn's dictionary is the third group of words, i.e. those words which he made himself as new derivatives; thus, he suggested completely new words for numerous firmly established

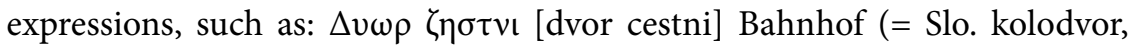
železniška postaja, Eng. railway station); C $\omega \pi \imath \chi \nu \lambda \alpha \kappa$ [sopihvlak] Lokomotive (Slo. lokomotiva, Eng. "engine, that puffs" = locomotive); Yワৎvav8\%

27 See Murko (1833), Stabej (1975: 50). 
[vesnavuk] Universität (Slo. univerza, vseučilišče, Eng. "all-the-knowledge” = university); etc. It is intriguing that he even substituted certain expressions that had been completely established in the literary language with new ones; two among these stand out, which are: "Вıрка [birka] Buchstabe", which he used as a substitute for the generally totally established expression "črka" (letter); and "Njıva [njivar] Bauer, Feldler, Landmann", which he used instead of "kmet" (peasant, farmer). As is generally typical for grammarians of this period, he suggested his own technical terms for some grammatical terms, such as: $\pi \varepsilon \rho \beta \varepsilon \sigma \eta \delta \kappa \alpha$ [perbesedka] Beiwort (adjective); $\pi \varepsilon \rho \sigma \tau \alpha v \kappa \alpha$ [perstavka] Beiwort (adjective); $\pi \varepsilon \rho \sigma \tau \alpha v \lambda \varepsilon v \kappa \alpha$ [perstavlenka] Eigenschaftswort (adjective); $\pi о \varsigma \tau \omega j \nu \kappa \alpha$ [postojnka] Strichpunct (semicolon); $\pi \rho \eta \beta \varepsilon \sigma \eta \delta \kappa \alpha$ [prebesedka] Vorwort (preface, foreword); etc.

\section{THE SECOND PART OF THE DICTIONARY}

The second part is a significantly shorter Slovenian-German dictionary, which has 82 pages and includes somewhat over 10,000 Slovenian words; Penn gave it another lengthy title:

Windisch-deutsches / Wörter-Buch / zum allgemeinen Gebrauche, besonders für / alle Geschäfts-Männer sowohl im weltlichen als / auch im geistlichen Stande in slavischen Ländern, / mit / beträchtlichen Vermehrungen der Wörter in / allen Amts-Geschäften, und heraus gegeben / im Jahre nach Geburt Christi / 1854. I Zweiter Theil.

The Slovenian-German dictionary for general use, especially all businessmen both of secular and clerical status in / Slovenian lands, with a significant increase in words of all business fields and published in the year after Christ's birth 1854 . Part two.

This part of the dictionary comprises 82.25 pages and includes entries

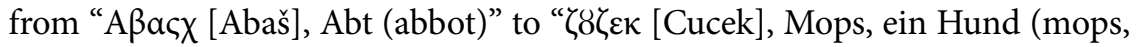
cur)". Entries follow each other according to the alphabetical order of the Slovenian alphabet: $\mathrm{A}-\mathrm{B}-\Delta-\mathrm{E}, \mathrm{H}-\Phi-\Gamma-\mathrm{X}-\mathrm{I}-\mathrm{J}-\mathrm{K}-\Lambda-\mathrm{M}-\mathrm{N}-\mathrm{O}, \Omega$ $-\Pi-\mathrm{P}-\Sigma-\mathrm{C} \chi-\mathrm{T}-8-\Upsilon-\mathrm{Z}$ (Image 7, Image 8). A few examples: A $\beta a \varsigma \chi\llcorner\alpha$,

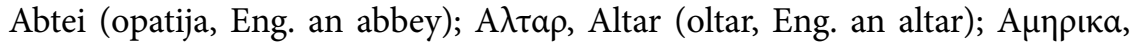
Amerika (Amerika, Eng. America); Baßı $\alpha$, Ambos (nakovalo, Eng. an anvil); Baßı $\alpha$, Elternmutter (babica, stara mati, Eng. a grandmother); Baßı $\alpha$, Hebamme (babica tj. pomočnica pri porodu, Eng. a midwife); Ba $\lambda \omega v$, Ballon, Luftball (balon, Eng. a baloon); $\beta a \tau \iota ~ \sigma \eta$, befürchten, sich fürchten (bati se, Eng. to fear, to be afraid of); $\beta \lambda \alpha \gamma \omega \varsigma \nu \eta \delta v o$, Eßwaren (živila, Eng. provisions); 
B.

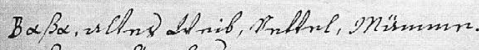

$B_{\alpha} \beta_{15 \alpha}$, Rinz $\beta_{n}$ ?

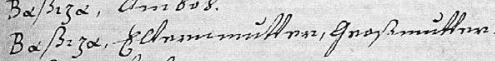

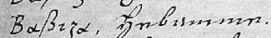

Bapover, Zijumat.

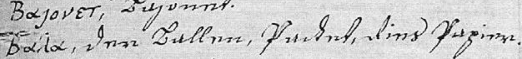

$3 \alpha 2,5 x$, ditslef if

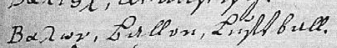

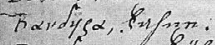

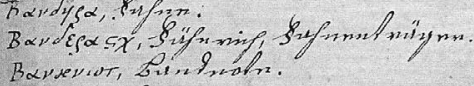

Bax's sy, sux.

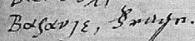

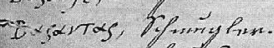

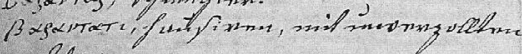

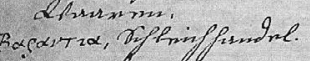

Baxpoti, finmeñm.

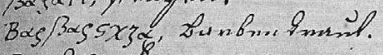

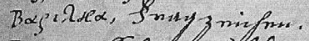

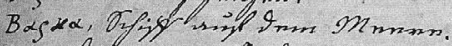

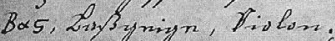

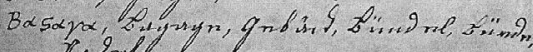

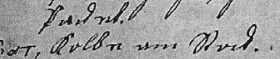

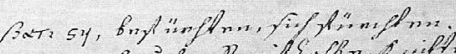

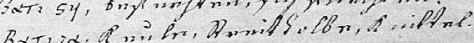

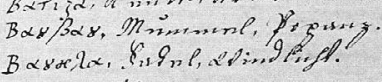

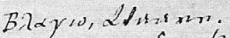

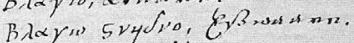

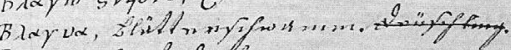

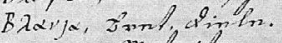

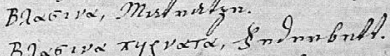

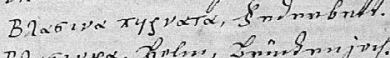

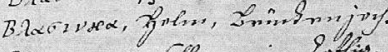

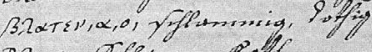

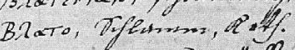

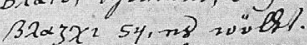

Bgadd, Bund in Mnentm.

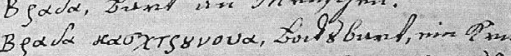

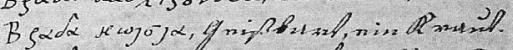

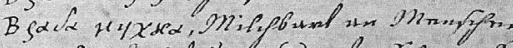

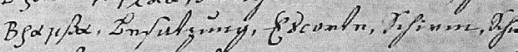
B sapes:sx, Dified.

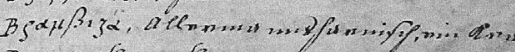

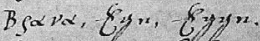

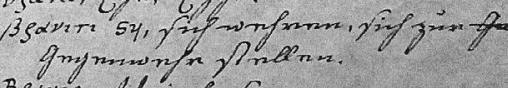

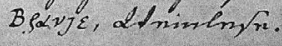

Image 7: Dominik Penn, Windisch-deutsches Wörter-Buch (1854), p. 1; source: NUK, Ms.

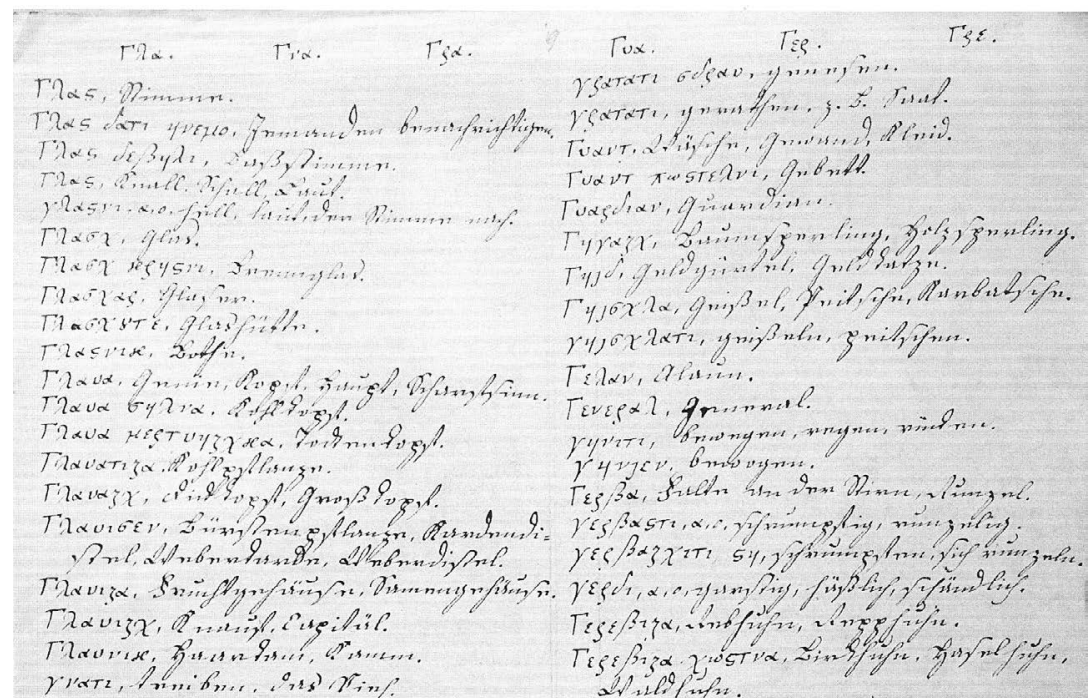

Image 8: Dominik Penn, Windisch-deutsches Wörter-Buch (1854), p. 4; source: NUK, Ms. 


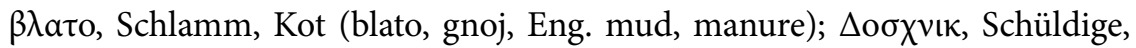

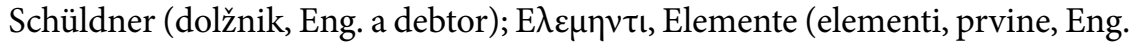
elements); E $\rho \delta \varepsilon \zeta \chi \vee v \alpha$, Rothe (rdečina, Eng. a redness); $\varphi$ oj!, pfui! (fuj!, Eng. yuck!); $\varphi \delta v \tau$, Pfund (funt, Eng. a pound); $\gamma \lambda \eta \delta \alpha \tau$, schauen, zusehen (gledati,

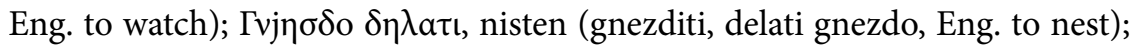

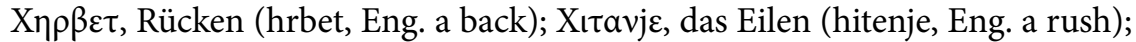
I $\sigma \delta a j a v \varepsilon \zeta$, Verräther (izdajalec, Eng. a traitor); Jaß8кa, Apfel (jabolko, Eng. an

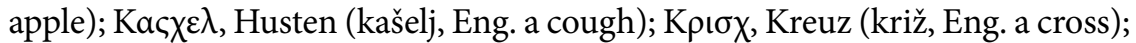

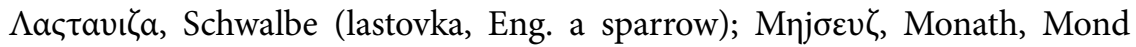

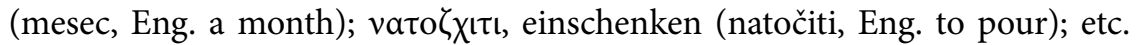
The second part of the dictionary was partly the result of Penn's independent work and collection of material, but the majority of the material was recapped after the published sources presented above and available to him. At the end, he

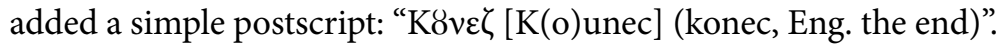

\section{SLOVENIAN GRAMMAR}

Penn's manuscript is rounded off by his Slovenska slovnica (Slovenische Sprachlehre, Slovenian Grammar), which is written in German and has only 24.25 pages in which, just like in the dictionary, he wrote the entire Slovenian text with Greek letters. As can be discerned from the manuscript, Dominik Penn completed his grammar on the 1 January 1854 . At the beginning of the grammar, he wrote an introduction, in which he explained what his purpose in writing a dictionary was and why he had added a grammar to it. First, he draws attention to his dictionary, to which he attributes too great a significance and too excessive a versatile usefulness; then he brings to the forefront the need for mastering the Slovenian language not only for businessmen and priests in the countryside but also in towns. Severe exaggeration is typical for the entire introduction; for one, he states that the number of Slovenianspeaking people in the Austrian monarchy far exceeds the number of all other nations in the monarchy. He explicitly mentions that there are not enough useful grammars for the learning of the Slovenian language; hence, he offers his own grammar to all who wish to perfect their knowledge of Slovenian; with its help, he strives to encourage as many people as possible to learn Slovenian, to perfect their Slovenian, and to use it in their literary endeavours. What he wrote was naturally not true, for from 1800 to the appearance of Dominik Penn's grammar, six Slovenian grammars were printed (Kopitar, Grammatik der Slavischen Sprache in Krain, Kärnten und Steyermark (1808 [1809]; Vodnik, Pismenost ali Gramatika sa Perve Shole (1811); Janez Leopold Šmigoc, Theoretisch-praktische Windische Sprachlehre (1812); Peter Dajnko, Lehrbuch der Windischen Sprache (1824); Franc Serafin Metelko, Lehrgebaude 
der Slowenischen Sprache im Königreiche Illyrien und in den benachbarten Provinzen (1825); Anton Janez Murko, Theoretisch-praktische Slowenische Sprachlehre für Deutsche (1832)), which in quality and scale surpassed Penn's, yet Penn simply ignored them. Penn in his work leaned most on the grammar by Janez Leopold Šmigoc $(1787-1829)^{28}$ which was entitled Theoretischpraktische Windische Sprachlehre (Theoretical and Practical Slovene Grammar); Penn and Šmigoc were schoolmates since they studied together at the university in Graz and were both very active in the Societas Slovenica, which encouraged the use of the Slovenian language, and Slovenian literature and culture. Comparison reveals that Penn's introduction is a plagiarism, since it summarises in an abbreviated form the text J.L. Šmigoc wrote at the beginning of his grammar book. He even recaps some of the thoughts from Šmigoc's introduction verbatim, but does not quote his source.

Penn's grammar book is very brief; it is divided into ten chapters and only presents the basics of individual word classes: it summarises nouns, adjectives, numerals, pronouns, verbs, adverbs, prepositions, conjunctions, and interjections, while the discussion is supplemented by a few examples and inflection patterns (Image 9). In the division of chapters, Penn more than obviously takes after Šmigoc's grammar and often presents dialectal forms as examples. A few are:

a) Declensions of the noun $\Delta o \beta \rho \omega \tau$ vik (benefactor)

\begin{tabular}{|c|c|c|c|c|c|}
\hline & $\varepsilon \delta ı v o$. & & 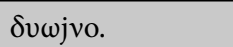 & & 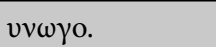 \\
\hline I. & $\Delta \mathrm{o} \beta \rho \omega \tau \nu \mathrm{I} \kappa$ & I. & $\Delta$ o $\beta \rho \omega \tau \nu \iota \kappa \alpha$ & I. & $\Delta \mathrm{o} \beta \rho \omega \tau \nu \mathrm{vi} \iota$ \\
\hline II. & $\Delta о \beta \rho \omega \tau \nu ı \kappa \alpha$ & II. & 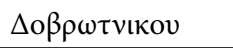 & II. & 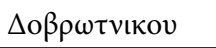 \\
\hline III. & $\Delta \mathrm{o} \beta \rho \omega \tau \nu$ เ $\mathrm{l}$ & III. & $\Delta о \beta \rho \omega \tau \nu \iota \kappa \alpha \mu$ & III. & $\Delta о \beta \rho \omega \tau \nu \iota \kappa о \mu$ \\
\hline IV. & $\Delta о \beta \rho \omega \tau \nu \iota \kappa \alpha$ & IV. & $\Delta$ o $\beta \rho \omega \tau \nu \iota \kappa \alpha$ & IV. & $\Delta \mathrm{o} \beta \rho \omega \tau \nu ı \kappa \varepsilon$ \\
\hline $\mathrm{V}$. & $v \Delta o \beta \rho \omega \tau v ı \kappa ı$ & $\mathrm{~V}$. & $v \Delta o \beta \rho \omega \tau v ı \kappa \alpha \chi$ & $\mathrm{V}$. & $v \Delta o \beta \rho \omega \tau v ı \kappa \alpha \chi$ \\
\hline VI. & $\sigma \Delta о \beta \rho \omega \tau \nu$ เко $\mu$ & VI. & $\sigma \Delta \mathrm{o} \beta \rho \omega \tau \nu ı \kappa \alpha \mu \alpha$ & VI. & 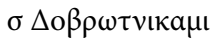 \\
\hline
\end{tabular}

b) Declensions of the noun $\Pi \eta \zeta \chi$ (furnace)

\begin{tabular}{|c|c|c|c|c|c|}
\hline & 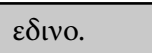 & & 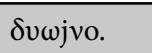 & & 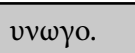 \\
\hline I. & $\Pi \eta \zeta \chi$ & I. & $\Pi_{\varepsilon} \zeta \chi \iota$ & I. & $\Pi_{\varepsilon} \zeta \chi \iota$ \\
\hline II. & $\Pi_{\varepsilon} \zeta \chi \mathrm{l}$ & II. & $\Pi \varepsilon \zeta \chi \eta \chi$ & II. & $\Pi \varepsilon \zeta \chi \eta \chi$ \\
\hline III. & $\Pi \eta \zeta \chi$ & III. & $\Pi \eta \zeta \chi \mu$ & III. & $\Pi \eta \zeta \chi \mu$ \\
\hline IV. & $\Pi \eta \zeta \chi$ & IV. & $\Pi \varepsilon \zeta \chi_{\downarrow}$ & IV. & $\Pi \varepsilon \zeta \chi \downarrow$ \\
\hline $\mathrm{V}$. & $v \Pi \eta \zeta \chi \iota$ & $\mathrm{V}$. & $v \Pi_{\varepsilon} \zeta \chi \eta \mu$ & $\mathrm{V}$. & $v \Pi_{\varepsilon} \zeta \chi \eta \chi$ \\
\hline VI. & $\sigma \Pi \varepsilon \zeta \chi j \omega j$ & VI. & $\sigma \Pi \eta \zeta \chi \mu \alpha$ & VI. & $\sigma \Pi_{\varepsilon} \zeta \chi \mu \iota$ \\
\hline
\end{tabular}

28 See Štrekelj (1922: 15), Kidrič (1930: 230 and footnote 274), Glazer (2013-c), Jelovšek (n.d.). 
c) Cardinal numerals from 1 to 20

\begin{tabular}{|c|c|c|c|}
\hline 1. & $\eta \delta \varepsilon v, \eta \nu, \eta v \alpha, \eta v o$ eins, eine, ein & 11. & $\varepsilon \delta v \eta j \varsigma \tau$ eilf \\
\hline 2. & $\delta v a, \delta v \eta, \delta v a$ zwei & 12. & $\delta v a v \eta j \varsigma \tau$ zwölf \\
\hline 3. & $\tau \rho ı j \varepsilon, \tau \rho ı, \tau \rho ı$ drei & 13. & $\tau \rho ı v \eta j \varsigma \tau$ dreizehn \\
\hline 4. & $\varsigma \chi \tau \iota \rho j \varepsilon, \varsigma \chi \tau \iota \rho \iota$ vier & 14. & $\varsigma \chi \tau \iota \rho \vee \eta j \varsigma \tau$ vierzehn \\
\hline 5. & $\pi \eta \tau$ fünf & 15. & $\pi \varepsilon \tau \vee \eta j \varsigma \tau$ fünfzehn \\
\hline 6. & $\varsigma \chi \eta \varsigma \tau$ sechs & 16. & $\varsigma \chi \varepsilon \varsigma \tau \vee \eta j \varsigma \tau$ sechszehn \\
\hline 7. & $\sigma \eta \delta \varepsilon v$ sieben & 17. & $\varsigma \varepsilon \delta v \eta j \varsigma \tau$ siebzehn \\
\hline 8. & $\omega \varsigma \varepsilon v$ acht & 18. & 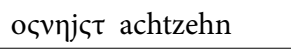 \\
\hline 9. & $\delta \varepsilon v \eta \tau$ neun & 19. & $\delta \varepsilon v \varepsilon \tau v \eta j \varsigma \tau$ neuzehn \\
\hline 10. & $\delta \varepsilon \varsigma \eta \tau$ zehn & 20. & 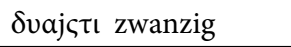 \\
\hline
\end{tabular}

č) Declensions of the personal pronoun for the $3^{\text {rd }}$ person [un 'he']

\begin{tabular}{|c|c|c|c|c|c|}
\hline \multicolumn{6}{|c|}{ dritte Person } \\
\hline I. & $8 v$ & I. & $8 v a$ & I. & $8 v \omega$ \\
\hline II. & 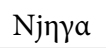 & II. & $\mathrm{Nj \eta}$ & II. & 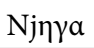 \\
\hline III. & 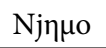 & III. & $\mathrm{Njı}$ & III. & 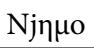 \\
\hline IV. & 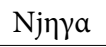 & IV. & $\mathrm{Nj \omega}$ & IV. & Ninja \\
\hline V. & $v v j \eta \mu$ & V. & $v$ vjij & V. & $v v j \eta \mu$ \\
\hline VI. & $\sigma v j ı \mu$ & VI. & $\sigma v j \omega j$ & VI. & $\sigma v j \eta \mu$ \\
\hline
\end{tabular}

Unlike the dictionary, which was directly or indirectly used by Fran Miklošič, Oroslav Caf, Matej Cigale, and Fran Pleteršnik, Dominik Penn's grammar book had no later reaction.

Penn's dictionary and grammar text includes practically no corrections, which indicates that this manuscript was probably already in its clean copy intended for potential printing. Did he intend to publish his dictionary and grammar? Obviously yes, for with the manuscript of the dictionary kept by the National and University Library in Ljubljana (NUK, Ms 1313) a sheet is preserved with a trial print of four dictionary entries meaning that, despite its peculiarity, Penn wanted to publish his dictionary material (Image 10). Why it did not happen is not known; his intention could have been prevented by his death in 1855. It is also not clear whether the sample print was made by Penn himself or any of the subsequent owners of the manuscript. 


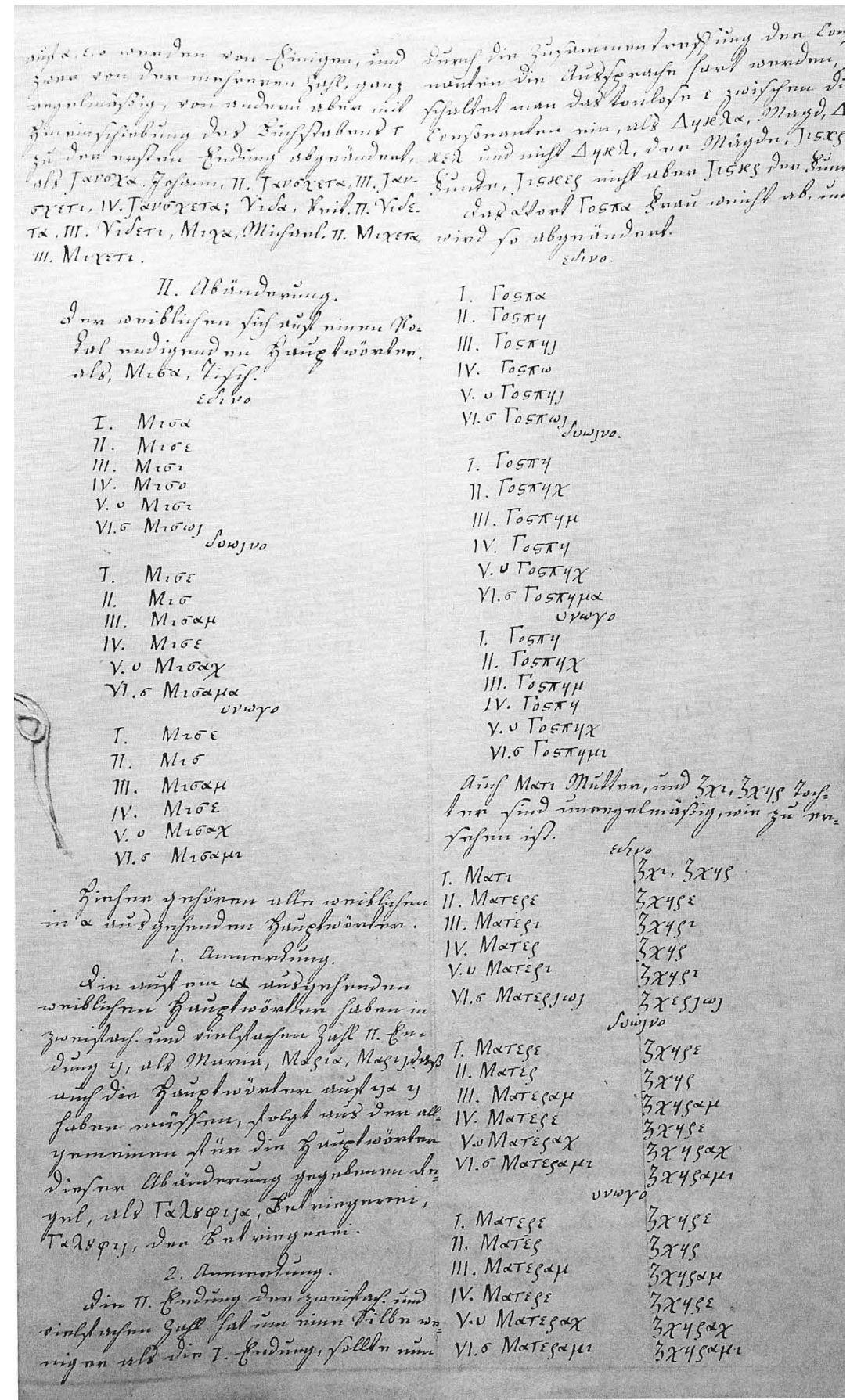

Image 9: Dominik Penn, Slovenische Sprachlehre (1854), example; source: NUK, Ms. 


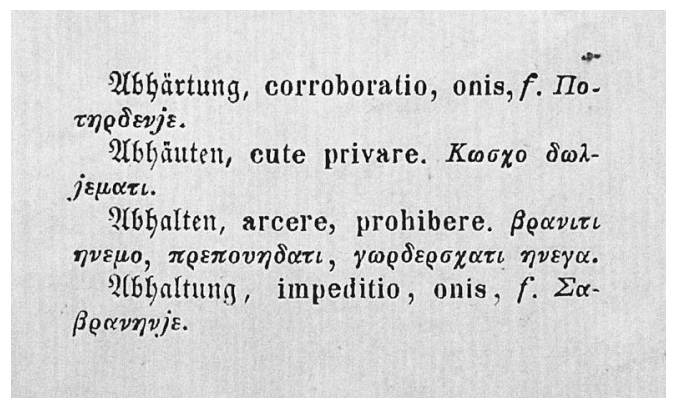

Image 10: Dominik Penn, sheet with a trial print, preserved in manuscript of the dictionary; source: NUK, Ms.

\section{CONCLUSION}

Is Dominik Penn's dictionary solely an interesting attempt at creating something special with the intention to avoid potential disputes with the leading linguists of his time and their linguistic directions? We can say for certain that that is not the case. Penn was undoubtedly led by a sincere desire to collect Slovenian vocabulary; the collection of words, which encompasses several hundred pages in manuscript, proves that he collected the material systematically and that his dictionary can be assigned among the greater lexicographic achievements of Penn's time, from which many remained in manuscript (e.g., the dictionary by Ivan Anton Apostel and the dictionary by Mihael Zagajšek); despite the fact that Penn's dictionary was never printed, it was still used by some of the most important Slovenian lexicographers in their work.

By writing the Slovenian language in the Greek alphabet, Penn introduced a new alphabet into the Slovenian territory: "grščica". Did he want to interfere in the polemic regarding the Slovenian alphabet with his unusual manner of recording Slovenian? Almost certainly not, since his intellectual reach was not of an extent that he could have more decidedly influenced the development of the Slovenian language. He did not want to actively touch upon the polemics regarding the use of the alphabet; it remains unknown whether he decided on this independent path, i.e. the writing of the Slovenian language with Greek letters, because he believed that other alphabets did not offer appropriate solutions, or because he did not want to participate in the disputes of his contemporaries, linguists. He could have been an eccentric himself and thus his lexicographic approach could not have been different. There was nobody among his contemporaries who imitated him and used his "grščica"; Penn himself probably never expected it, since writing Slovenian with the "grščica" alphabet would be, despite some of its advantages, simply too complicated and demanding not only due to the rules of writing but also 
because the use of such alphabet would have been limited to a very small circle of users, i.e. to those fluent in Greek. All others would have to have learned at least some basics of the language, which was difficult in Penn's time. Namely, Greek was familiar only to those who enrolled in high school, while a knowledge of Greek would have been absolutely unattainable for the wider masses since there were no Slovenian textbooks to learn it from. Everything written about why Penn decided to use "grščica" is simply a speculation, for he never explained and substantiated his decision. It would be of immense help if some kind of legacy were found, such as correspondence or archival material that would shed some light on the background of his work; however, the chances of that are quite slim. Despite the fact that Penn's work did not find an echo in Slovenian literature, that Dominik Penn himself remained fairly unknown in the Slovenian territory, and that his work is considered to be a sort of boutique professional experiment, his dictionary remains an intriguing documentary peculiarity not only in the Slovenian but also wider European territory.

\author{
Matej Hriberšek \\ University of Ljubljana \\ matej.hribersek@ff.uni-lj.si
}

\title{
ABBREVIATIONS
}

NUK, Ms: Narodna in univerzitetna knjižnica (National and University Library), Zbirka rokopisov, redkih in starih tiskov (Manuscript, Rare and Old Prints Collection).

ŠAM: Nadškofijski arhiv Maribor (Archdiocesan Archives Maribor).

UKM, Ms: Univerzitetna knjižnica Maribor (University Library Maribor), Enota za domoznanstvo in posebne zbirke (Local History and Special Collections Department).

\section{BIBLIOGR APHY}

Ahačič, Kozma. 2007. Zgodovina misli o jeziku in književnosti na Slovenskem: protestantizem. Ljubljana: Založba ZRC, ZRC SAZU.

Ahačič, Kozma. 2013. "Bohorič, Adam (okoli 1520-po 1598)." Slovenska biografija. Ljubljana: Slovenska akademija znanosti in umetnosti, Znanstvenoraziskovalni center SAZU. Accesed November 21, 2020. http://www.slovenska-biografija.si/oseba/ sbi145314/\#novi-slovenski-biografski-leksikon. First published in Barbara Šterbenc Svetina et al., eds., 3. zv.: Ble-But.

Atelšek, Simon. 2013. "Cigale, Matej (1819-1889)." Slovenska biografija. Ljubljana: Slovenska akademija znanosti in umetnosti, Znanstvenoraziskovalni center SAZU. Accessed November 14, 2020. http://www.slovenska-biografija.si/oseba/ 
sbi158709/\#novi-slovenski-biografski-leksikon. First published in Barbara Šterbenc Svetina et al., eds. (online edition).

Bjelčevič, Aleksander, Matija Ogrin, and Urška Perenič, eds. 2017. Rokopisi slovenskega slovstva od srednjega veka do moderne. Simpozij (Symposium) Obdobja 36. Ljubljana: Znanstvena založba Filozofske fakultete, 2017.

Breznik, Anton. 1938. "Iz zgodovine novejših slovenskih slovarjev." Časopis za zgodovino in narodopisje 33 (1): 17-32, 87-98, 147-165.

Breznik, Anton. 2013. "Pleteršnik, Maks (1840-1923)." Slovenska biografija. Ljubljana: Slovenska akademija znanosti in umetnosti, Znanstvenoraziskovalni center SAZU, 2013. Accessed November 14, 2020. http://www.slovenska-biografija.si/oseba/ sbi435041/\#slovenski-biografski-leksikon. First published in Izidor Cankar et al., eds., 7. zv.: Peterlin-Pregelj $C$.

Caf, Oroslav. 1871. “P. Bernardus, capucinus Marburgensis 1760.” Slovenski narod 4 (137): 1.

Cankar, Izidor, et al., eds. 1925-1991. Slovenski biografski leksikon. 16 vols. Ljubljana: Zadružna gospodarska banka.

Cigale, Matej. 186o. Deutsch-slovenisches Wörterbuch. Erster Theil, A-L. Zweiter Theil, $M-Z$. Laibach: Josef Blasnik.

Dajnko, Peter. 1824. Lehrbuch der Windischen Sprache. Ein Versuch zur gründlichen Erlernung derselben für Deutsche, zur vollkommeneren Kenntniß für Slowenen. Grätz: Johann Andreas Kienreich.

Ditmajer, Nina. 2019. Sprejemanje vzhodnoštajerske knjižnojezikovne norme v rokopisnih pridigah Jožefa Muršca. PhD diss., University of Maribor.

Fekonja, Andrej. 1891. “Kratka povestnica slovenskega pravopisa.” Ljubljanski zvon 11 (11): 611-618, 668-675, 719-725.

Glaser, Karel. 1896. Zgodovina slovenskega slovstva. 2. zv., Od francoske revolucije do 1848 l. Ljubljana: Slovenska Matica.

Glazer, Janko. 2013-a. "Krempl, Anton (1790-1844)." Slovenska biografija. Ljubljana: Slovenska akademija znanosti in umetnosti, Znanstvenoraziskovalni center SAZU. Accessed November 21, 2020. http://www.slovenska-biografija.si/oseba/ sbi303945/\#slovenski-biografski-leksikon. First published in Izidor Cankar et al., eds., 4. zv.: Kocen-Lužar.

Glazer, Janko. 2013-b. "Murko, Anton (1809-1871)." Slovenska biografija. Ljubljana: Slovenska akademija znanosti in umetnosti, Znanstvenoraziskovalni center SAZU. Accessed November 23, 2020. http://www.slovenska-biografija.si/oseba/ sbi380348/\#slovenski-biografski-leksikon. First published in Izidor Cankar et al., eds., 6. zv.: Mrkun-Peterlin.

Glazer, Janko. 2013-c. “Šmigoc, Janez Krstnik Leopold (1787-1829).” Slovenska biografija. Ljubljana: Slovenska akademija znanosti in umetnosti, Znanstvenoraziskovalni center SAZU. Accessed November 16, 2020. http://www.slovenska-biografija.si/oseba/sbi66o226/\#slovenski-biografski-leksikon. First published in Izidor Cankar et al., eds., 11. zv.: Stelè-Švikaršič.

Gutsman, Oswald. 1789. Deutsch-windisches Wörterbuch mit einer Sammlung der verdeutschten windischen Stammwörter, und einiger vorzüglichern abstammenden Wörter. Klagenfurt: Ignaz Aloys von Kleinmayr.

Harrauer, Christine, and Hubert Reitterer. 1995. "Schönberger, P. Andreas Corsinus (Franz Xav.) (1754-1820), Lehrer." Österreichisches biographisches Lexikon 1815-1950. Bd. 11 (Lfg. 51), 49-50. Wien: Verlag der Österreichischen Akademie der Wissenschaften. 
Hartman, Bruno. 1998. Hoški nadžupnik in dekan dr. Anton Murko (1809-1871), jezikoslovec in utrjevalec slovenskega knjižnega jezika. Hoče: Turistično društvo.

Hriberšek, Matej. 2008. “Slovaropisje klasičnih jezikov na Slovenskem v 16. stoletju.” Slavia Centralis 1 (2): 77-87.

Ilešič, Fran. 1905-a. "Korespondenca dr. Jos. Muršca." Zbornik znanstvenih in poučnih spisov 7:1-210.

Ilešič, Fran. 1905-b. Korespondenca dr. Jos. Muršca. Ponatisk iz »Zbornika Matice Slovenske« za l. 1904 in 1905. Ljubljana: Naroda tiskarna.

Ilešič, Fran. 1905-c. "Iz prvih časov romantike." Časopis za zgodovino in narodopisje 2:1-68.

Ilešič, Fran. 1939. "P. Bernard Mariborčan, slovenski pisatelj 18. stoletja." Časopis za zgodovino in narodopisje 34:39-97.

Janežič, Anton. 1858. "Glasnik iz domačih in tujih krajev. Iz Marburga." Glasnik slovenski $10(2): 172$.

Janežič, Anton. 1850. Popólni ročni slovár slovénskega in némškega jezika./Vollständiges Taschen-Wörterbuch der slovenischen und deutschen Sprache. Nemško-slovenski del./Deutsch-slovenischer Theil. U Celóvcu/Klagenfurt: V zalóžbi J. Sigmundove knjigárnice v Celóvcu/Im Verlage der J. Sigmund'schen Buchhandlung.

Janežič, Anton. 1851. Popólni ročni slovár slovénskega in némškega jezika. Vollständiges Taschen-Wörterbuch der slovenischen und deutschen Sprache. Slovensko-nemški del./Slovenisch-deutscher Theil. U Celóvcu/Klagenfurt: V zalóžbi J. Sigmundove knjigárnice v Celóvcu/Im Verlage der J. Sigmund’schen Buchhandlung.

Jarnik, Urban. 1832. Versuch eines Etymologikons der slowenischen Mundart in InnerÖsterreich. Klagenfurt: Ferdinand Kleinmayr.

Jelovšek, Alenka. n.d. "Janez Krstnik Leopold Šmigoc. Theoretisch-praktische Windische Sprachlehre." In Slovenske slovnice in pravopisi: spletǐ̌če slovenskih slovnic in pravopisov od 1584 do danes, edited by Kozma Ahačič. Accessed November 15, 2020. https://www.fran.si/slovnice-in-pravopisi/13/1812-smigoc.

Jesenšek, Marko, and Bernard Rajh, eds. 1998. Dajnkov zbornik. Zora 3. Maribor: Slavistično društvo.

Jesenšek, Marko, ed. 1999-a. Murkov zbornik: Referati s Simpozija Anton Murko in njegov čas. Maribor: Slavistično društvo.

Jesenšek, Marko. 1999-b. "Slovaropisje na Štajerskem do konca 19. stoletja." Časopis za zgodovino in narodopisje 70 (1-2): 355-371.

Jesenšek, Marko. 2015. Poglavja iz zgodovine vzhodnoštajerskega jezika. Mednarodna knjižna zbirka Zora 11o. Maribor: Mednarodna založba Oddelka za slovanske jezike in književnosti, Filozofska fakulteta.

Kacin, Anton. 2013. “Cigale, Matej (1819-1889).” Slovenska biografija. Ljubljana: Slovenska akademija znanosti in umetnosti, Znanstvenoraziskovalni center SAZU. Accessed November 14, 2020. http://www.slovenska-biografija.si/oseba/sbi158709/\#primorskislovenski-biografski-leksikon. First published in Primorski slovenski biografski leksikon, 3. snopič: Bor-Čopič, 1. knjiga. Gorica: Goriška Mohorjeva družba, 1976.

Kidrič, France. 1929. Zgodovina slovenskega slovstva. Od začetkov do marčne revolucije. Razvoj, obseg in cena pismenstva, književnosti in literature. Ljubljana: Slovenska matica.

Kidrič, Francè. 1930. Dobrovský in slovenski preporod njegove dobe. Razprave Znanstvenega društva v Ljubljani 7, Historični odsek 1. Ljubljana: J. Blasnika nasl. Univerzitetna tiskarna. 
Kidrič, France. 1934-a. “Ustanovitev slovenske stolice v Ljubljani.” Ljubljanski zvon $54: 208-215,300-307,374-382$.

Kidrič, France. 1934-b. KorespondencaJaneza Nepomuka Primca18o8-1813. Korespondence pomembnih Slovencev 1. Ljubljana: Znanstveno društvo.

Kidrič, Francè. 2013-a. "Apostel, Ivan Anton (1711-1784).” Slovenska biografija. Ljubljana: Slovenska akademija znanosti in umetnosti, Znanstvenoraziskovalni center SAZU. Accessed November 14, 2020. http://www.slovenska-biografija.si/oseba/ sbi130201/\#slovenski-biografski-leksikon. First published in Izidor Cankar et al., eds., 1. zv.: Abraham-Erberg.

Kidrič, Francè. 2013-b. "Dajnko, Peter (1787-1873)." Slovenska biografija. Ljubljana: Slovenska akademija znanosti in umetnosti, Znanstvenoraziskovalni center SAZU. Accessed November 22, 2020. http://www.slovenska-biografija.si/oseba/ sbi168756/\#slovenski-biografski-leksikon. First published in Izidor Cankar et al., eds., 1. zv.: Abraham-Erberg.

Kidrič, Francè. 2013-c. "Pen, Dominik (1785-1855)." Slovenska biografija. Ljubljana: Slovenska akademija znanosti in umetnosti, Znanstvenoraziskovalni center SAZU. Accessed November 22, 2020. http://www.slovenska-biografija.si/oseba/sbi411625/\#slovenski-biografski-leksikon. First published in Izidor Cankar et al., eds., 6. zv.: Mrkun-Peterlin.

Kolarič, Rudolf. 2013-a. "Caf, Oroslav (1814-1874)." Slovenska biografija. Ljubljana: Slovenska akademija znanosti in umetnosti, Znanstvenoraziskovalni center SAZU. Accessed November 15, 2020. http://www.slovenska-biografija.si/oseba/ sbi154664/\#slovenski-biografski-leksikon. First published in Izidor Cankar et al., eds., 1. zv.: Abraham-Erberg.

Kolarič, Rudolf. 2013-b. “Cigale, Matej (1819-1889)." Slovenska biografija. Ljubljana: Slovenska akademija znanosti in umetnosti, Znanstvenoraziskovalni center SAZU. Accessed November 14, 2020. http://www.slovenska-biografija.si/oseba/ sbi158709/\#slovenski-biografski-leksikon. First published in Izidor Cankar et al., eds., 1. zv.: Abraham-Erberg.

Kolarič, Rudolf. 2013-c. "Metelko, Franc Serafin (1789-1860)." Slovenska biografija. Ljubljana: Slovenska akademija znanosti in umetnosti, Znanstvenoraziskovalni center SAZU. Accessed November 22, 2020. http://www.slovenska-biografija.si/oseba/sbi363425/\#slovenski-biografski-leksikon. First published in Izidor Cankar et al., eds., 5. zv.: Maas-Mrkun.

Kotnik, Fran. 1919. “'Sprotuletna Vijolica,' mariborski dijaški list iz leta 1846." Časopis za zgodovino in narodopisje 15 (1): 114-126.

Legiša, Lino. 1959. Zgodovina slovenskega slovstva. 2. zv., Romantika in realizem I. Ljubljana: Slovenska matica.

Lenard, Leopold. 1909. "Dr. Ljudevit Gaj." Dom in svet 22:427-428, 472-475, 517-519, $558-569$.

Logar, Janez. 2013. "Megiser, Hijeronim (med 1554 in 1555-1619)." Slovenska biografija. Ljubljana: Slovenska akademija znanosti in umetnosti, Znanstvenoraziskovalni center SAZU. Accessed November 22, 2020. http://www.slovenska-biografija.si/oseba/sbi357106/\#slovenski-biografski-leksikon. First published in Izidor Cankar et al., eds., 5. zv.: Maas-Mrkun.

Lokar, Jože. 1957-1958. “Dve stoletnici.” Jezik in slovstvo 3 (3): 102-109.

Macun, Ivan. 1883. Književna zgodovina Slovenskega Štajerja. Graz: printed by the author. 
Medved, Anton. 1895. “Anton Krempl.” Dom in svet 8 (21): 641-643.

Megiser, Hieronymus. 1744. Dictionarium quatuor linguarum videlicet Germanicae, Latinae, Illyricae (quae vulgo Sclavonica) \& Italicae, sive Hetruscae. Auctore Hieronymo Megisero Impressum Graecii Styriae à Ioanne Fabro ... nunc vero auspiciis Excellentisiimi Domini, Domini Supremi Carinthiae Capitanei Opera \& Studio A.A. R.R. P.P. Societ. JESU Collegii Clagenfurtensis correctum \& auctum. Clagenfurti: typis Ioannis Friderici Kleinmayr.

Metelko, Franc Serafin. 1825. Lehrgebaude der slowenischen Sprache in Königreiche Illyrien und in den benachbarten Provinzen: Nach dem Lehrgebäude der böhm. Sprache des Hrn. Abbé Dobrowsky. Laibach: Leopold Eger.

Murko, Anton. 1832-1833. Şlovénsko-némshki in némshko-şlovénski rózhni besédnik, sráven kràtke slovénske gramátike sa Némze: kakor se slovénshina govori na Şhtájerskim, Koròshkim, Krájnskim in v'sahodnih stranih na Vógerskim. Şlovénskonémshki dél. V' Grádzi: v' salógi in na prodaj per Fr. Ferstli: Janes Lavre Greiner.

Orel, Irena. 2017. "Pomen starejših rokopisov za slovensko zgodovinsko jezikoslovje." In Aleksander Bjelčevič et al., eds., 253-266.

Pajek, Jožef. 188o. “Dr. Anton Murko. Životopis. Sestavil dr. Jož. Pajek.” Letopis Matice Slovenske za leto 1880, edited by Dr. Janez Bleiweis, 224-257. Ljubljana: Matica Slovenska.

Petrè, Fran. 1939. Poizkus ilirizma pri Slovencih (1835-1849). Ljubljana: Slovenska matica.

Pirjevec, Avgust. 1924. "Maks Pleteršnik." Ljubljanski zvon 44 (4): 240-244, 304-311, 361-371.

Pleteršnik, Maks, ed. (1893) 1894-1895. Slovensko-nemški slovar. Izdan na troške rajnega knezoškofa ljubljanskega Antona Alojzija Wolfa. Prvi del, A-O. Drugi del, $P-\check{Z}$. V Ljubljani: Knezoškofijstvo (Katoliška tiskarna).

Pohlin, Marko. 1792. Glossarium Slavicum in supplementum ad primam partem Dictionarii Carniolici. Viennae: Literis Grosserianis.

Pohlin, Marko. 1781. Tu malu besedishe treh jesikov. Das ist: Das kleine Wörterbuch in dreyen Sprachen. Quod est: parvum dictionarium trilingue, quod conscripsit $R$. $P$. Marcus a S. Antonio Paduano Augustinianus discalceatus inter academicos operosos Labacenses dictus: Novus. Laibach: Johann Friedrich Eger.

Prijatelj, Ivan. 1935. Duševni profili slovenskih preporoditeljev. Za šestdesetletnico izdali Prijateljevi učenci. Ljubljana: s.n.

Prunč, Erich. 1983. "Primic Janez Nep." Österreichisches Biographisches Lexikon 1815-1950. Bd. 8:281. Wien: Verlag der Österreichischen Akademie der Wissenschaften.

Raič, Božidar. 1869. “A. Kremplj.” Národni koledar, Sporočilo in Letopis Matice Slovenske za leto 1869:86-94. Ljubljana: Jožef Blaznik.

Raič, Božidar. 1878. “Oroslav Caf.” Letopis Matice slovenske 3-4:72-101.

Rajh, Bernard, ed. 1998. Dajnkovo berilo. Maribor: Slavistično društvo.

Rajhman, Jože. 1998. “Dajnkov jezikovni nazor.” In Marko Jesenšek and Bernard Rajh, eds., $57-69$.

Scheller, Immanuel Johann Gerhard, G. H. Lünemann and Franz Xaver Schönberger. 1818-1820. Imm. Joh. Gerb. Schellers lateinisch-deutsches und deutsch-lateinisches Hand-Lexikon vornehmlich für Schulen, von neuen durchgesehen, verbessert und vermehrt durch G. H. Lünemann, Doctor der Philosophie, und Lehrer der griechischen und lateinischen Sprache am Gymnasio zu Göttingen, zu einem allgemeineren Gebrauche mit beträchtlichen Vermehrungen herausgegeben von Franz 
Xaver Schönberger. 3 Bände. Wien und Triest: im Verlage der Geistinger'schen Buchhandlung.

Slodnjak, Breda. 2013. "Primic, Janez Nepomuk (1785-1823)." Slovenska biografija. Ljubljana: Slovenska akademija znanosti in umetnosti, Znanstvenoraziskovalni center SAZU. Accessed November 20, 2020. http://www.slovenska-biografija.si/oseba/sbi470396/\#slovenski-biografski-leksikon. First published in Izidor Cankar et al., eds., 8. zv.: Pregelj Ivan-Qualle.

Stabej, Jože. 1972. "Janez Anton Apostel-pater Bernard: Dictionarium GermanicoSlavonicum 1760." Časopis za zgodovino in narodopisje 43:263-274.

Stabej, Jože. 1975. "Slovarnik Vid (Dominik) Penn.” Slavistična revija 23 (1): 41-58.

Stabej, Marko. 20o1. "Peter Danjko in njegova dajnčica." Slovenska kronika XIX. stoletja, edited by Janez Cvirn et al., 16o. Ljubljana: Nova revija.

Šlebinger, Janko. 2013. "Macun, Ivan (1821-1883).” Slovenska biografija. Ljubljana: Slovenska akademija znanosti in umetnosti, Znanstvenoraziskovalni center SAZU. Accessed November 15, 2020. http://www.slovenska-biografija.si/oseba/sbi337395/\#slovenskibiografski-leksikon. First published in Izidor Cankar et al., eds., 5. zv.: Maas-Mrkun.

Šrimpf, Franc. 1972. "Oroslav Caf, slovenski sanskrtist, filolog in tragična osebnost.” Dialogi $8: 498-515$.

Šterbenc Svetina, Barbara et al., eds. 2013-. Novi Slovenski biografski leksikon. Ljubljana: Znanstvenoraziskovalni center SAZU.

Štrekelj, Karel. 1922. Historična slovnica slovenskega jezika. Maribor: Zgodovinsko društvo, Družba sv. Mohorja.

Šumrada, Janez. 2002. "Janez Nepomuk Primic in ustanovitev stolice za slovenski jezik na liceju v Gradcu 1811." Slavistična revija 50 (1): 51-60.

Toš, Marjan. 2014. "Ob 20o-letnici rojstva in 140-letnici smrti Oroslava (Jurija) Cafa, slovenskogoriškega rojaka od Svete Trojice." Časopis za zgodovino in narodopisje $85=50(4): 5-18$.

Vidmar, Luka. 2013. “Apostel, Ivan Anton (1711-1784)." Slovenska biografija. Ljubljana: Slovenska akademija znanosti in umetnosti, Znanstvenoraziskovalni center SAZU. Accessed November 14, 2020. http://www.slovenska-biografija.si/oseba/ sbi130201/\#novi-slovenski-biografski-leksikon. First published in Barbara Šterbenc Svetina et al., eds., 1. zv.: A.

Vrbanov, J. G. 1898. "Dr. Jožef Muršec. (Životopis. Spisal J. G. Vrbanov).” Slovenske Večernice za pouk in kratek čas 51:1-64.

von Wurzbach, Constantin. 1872. "Primiz, Johann Nepomuk.” Biographisches Lexikon des Kaiserthums Oesterreich 23:309-310.

von Wurzbach, Constantin. 1876. "Schönberger, Franz Xaver." Biographisches Lexikon des Kaiserthums Oesterreich 31:127-128. 


\section{POVZETEK}

\section{$\mathrm{Na}$ presečišču med slovenščino in grščino: leksikograf Dominik Penn in njegovo delo}

Vid Penn se je rodil v vasi Sveti Vid pri Ptuju 5. maja 1785; po končani osnovni šoli in nato gimnaziji v Mariboru ter dvoletnem študiju filozofije je študiral teologijo na Univerzi v Gradcu (1810-1814). Tam se je pridružil Slovenskemu društvu (Societas Slovenica), katerega člani so se posvečali ohranjanju in raziskovanju slovenskega jezika; v tem času je vstopil v red minoritov in si izbral redovno ime Dominik. Kot duhovnik je deloval na ožjem območju Ptuja in njegove okolice na župnijah, ki so jih upravljali minoriti. Umrl je na Ptuju 14. aprila 1855.

Dolgo je bilo Pennovo slovarsko delo znano le redkim izobražencem in slovaropiscem: Franu Miklošiču, Jožefu Muršču, Maksu Pleteršniku, Antonu Janežiču, Oroslavu Cafu, Božidarju Raču in Mateju Cigaletu. Njegov slovar je nastajal v obdobju med letoma 1824 in 1854 . Obsega skupno 590 strani, razdeljen pa je na tri dele. Prvi del je nemško-latinsko-slovenski slovar, ki obsega 471 strani; iz Pennove spremne besede izvemo, kaj je bil neposredni povod za delo in zakaj se je zanj odločil. Za osnovo slovarja je Penn izbral delo avstrijskega šolnika Andreasa Corsinusa (Franza Xaverja) Schönbergerja, in sicer njegovo priredbo Scheller-Lünemannovega Latinsko-nemškega in nemško-latinskega slovarja (Imm. Joh. Gerb. Schellers lateinisch-deutsches und deutsch-lateinisches Hand-Lexikon), ki je izhajal na Dunaju v letih 1818-1820. Slovarska gesla v tem delu slovarja so razporejena po abecednem vrstnem redu nemške abecede; vedno je najprej napisano nemško geslo, sledi mu latinsko in na koncu slovensko, pogosto pa so pri geslih predstavljene tudi besedne zveze. Nemško besedilo je Penn zapisoval s pisano gotico, latinske besede v latinici, za zapisovanje slovenskih besed pa je uvedel zapisovanje z grškimi črkami in tega črkopisa se je oprijelo ime grščica; zanjo je pripravil tudi poseben sistem zapisovanja $\mathrm{z}$ grškimi črkami $(\alpha, A ; \beta$, B; $\delta, \Delta ; \varepsilon, \mathrm{E} ; \eta, \mathrm{H} ; \varphi, \Phi ; \gamma, \Gamma ; \chi, \mathrm{X} ; \mathrm{l}, \mathrm{I} ; \mathrm{j}, \mathrm{J} ; \kappa, \mathrm{K} ; \lambda, \Lambda ; \mu, \mathrm{M} ; \nu, \mathrm{N} ; \mathrm{o}, \mathrm{O}, \omega, \Omega ; \pi, \Pi ; \rho, \mathrm{P} ; \sigma, \Sigma, \varsigma$, C, $\sigma \chi, \Sigma \chi, \varsigma \chi, C \chi ; \tau, T ; 8,8 ; v, \Upsilon ; \zeta, Z ; \zeta \chi, Z \chi)$, crko $j, J$ je prevzel iz latinice, iz stare cerkvene slovanščine pa je prevzel črko $u k(8,8)$, ki je nadomestila dvočrkje ou. Slovensko besedje v slovarju lahko razdelimo na tri skupine: $v$ prvi skupini so besede, ki jih lahko označimo kot knjižne, drugo skupino tvorijo besede, ki jih lahko opredelimo kot tipično narečne, v tretjo skupino pa besede, ki so Pennove novotvorjenke,

Drugi del je slovensko-nemški slovar, ki je znatno krajši; obsega le 82 strani. Slovarska gesla si sledijo po abecednem vrstnem redu slovenske abecede $(\mathrm{A}-\mathrm{B}-\Delta-\mathrm{E}, \mathrm{H}-\Phi-\Gamma$ - X - I - J - K - $\Lambda$ - M - N - O, $\Omega-\Pi-\mathrm{P}-\Sigma-\mathrm{C} \chi-\mathrm{T}-8-\Upsilon-\mathrm{Z}$ ). Zbrano besedje je rezultat deloma Pennovega samostojnega dela, velik del gradiva pa je zbral iz že natisnjenih jezikovnih virov.

Pennov rokopis zaključuje kratka, v nemščini napisana Slovenska slovnica (Slovenische Sprachlehre), ki obsega 24 strani, z uvodom, povzetim iz uvoda, ki ga je napisal Janez Leopold Šmigoc k svoji Theoretisch-praktische Windische Sprachlehre; v njem je pojasnil, zakaj se je lotil priprave slovarja in zakaj mu je dodal tudi slovnico. Ta je razdeljena na deset poglavij, v katerih na kratko predstavi posamezne besedne vrste.

Rokopis Pennnovega slovarja nima skoraj nobenih popravkov, kar nakazuje, da je verjetno šlo že za čistopis, pripravljen za morebitni natis. Penn je slovar očitno nameraval natisniti in objaviti, kar potrjuje tudi listič, ohranjen na koncu rokopisa, s poskusno tiskarsko postavitvijo in natisom štirih slovarskih gesel; namero mu je najbrž preprečila njegova smrt 
leta 1855. Delo Dominika Penna ostaja razmeroma slabo znano in precej pozabljeno tako v zgodovini slovenske književnosti kot tudi v zgodovini slovenskega slovaropisja; v znanstveni in strokovni literaturi najdemo o njem le dva prispevka ter nekaj krajših omemb. Vendar pa ostaja njegov slovar prav zaradi grščice, ki jo je uvedel, zanimiva dokumentarna posebnost ne le v slovenskem, ampak tudi v širšem evropskem prostoru.

\begin{abstract}
Although the Slovenian language is relatively small, Slovenian lexicography has quite a rich history and tradition reaching right back to the 16th century. Until the 19th century, writers who made dictionaries and collections of Slovenian vocabulary prepared a fair amount of admirable works, albeit many remained in manuscript and have never been printed. In the 19th century, the study of the Slovenian language, efforts to preserve it, and the collecting of Slovenian linguistic material spread outside the central Slovenian land of Carniola; in Styria in particular, young intellectuals from those parts, such as Leopold Volkmer (1741-1816), Janez Krstnik Leopold Šmigoc (1787-1829), Peter Dajnko (1787-1873), Anton Krempl (1790-1844), and others, provided for the collecting of linguistic material alongside their literary endeavours; one of them was Friar Minor Dominik Penn. He was a fascinating lexicographer who included Greek in his work in a very unusual way.
\end{abstract}

Keywords: Ancient Greek, Dominik Penn, grščica, Slovenian dictionaries, lexicography

\title{
IZVLEČEK
}

Slovensko slovaropisje ima glede na to, da je slovenščina razmeroma majhen jezik, precej bogato zgodovino in tradicijo, ki sega vse tja do 16. stoletja. Pisci, ki so pripravljali slovarje in zbirke slovenskega besedja, so do 19. stoletja ustvarili kar nekaj zanimivih in obsežnih del. A večina jih je ostala v rokopisu in niso bila nikoli natisnjena. V 19. stoletju se je raziskovanje slovenskega jezika, skrb zanj in zbiranje slovenskega jezikovnega gradiva razmahnilo tudi zunaj osrednje slovenske dežele Kranjske; zlasti na Štajerskem so tamkajšnji mladi intelektualci (na primer Leopold Volkmer (1741-1816), Janez Krstnik Leopold Šmigoc (1787-1829), Peter Dajnko (1787-1873), Anton Krempl (1790-1844)) ob literarnem ustvarjanju skrbeli tudi za zbiranje jezikovnega gradiva; mednje spada tudi minorit Dominik Penn, izjemno zanimiv slovaropisec, ki je na nenavaden način v svoje delo vpletel grščino.

Ključne besede: stara grščina, Dominik Penn, grščica, slovenski slovarji, leksikografija 